
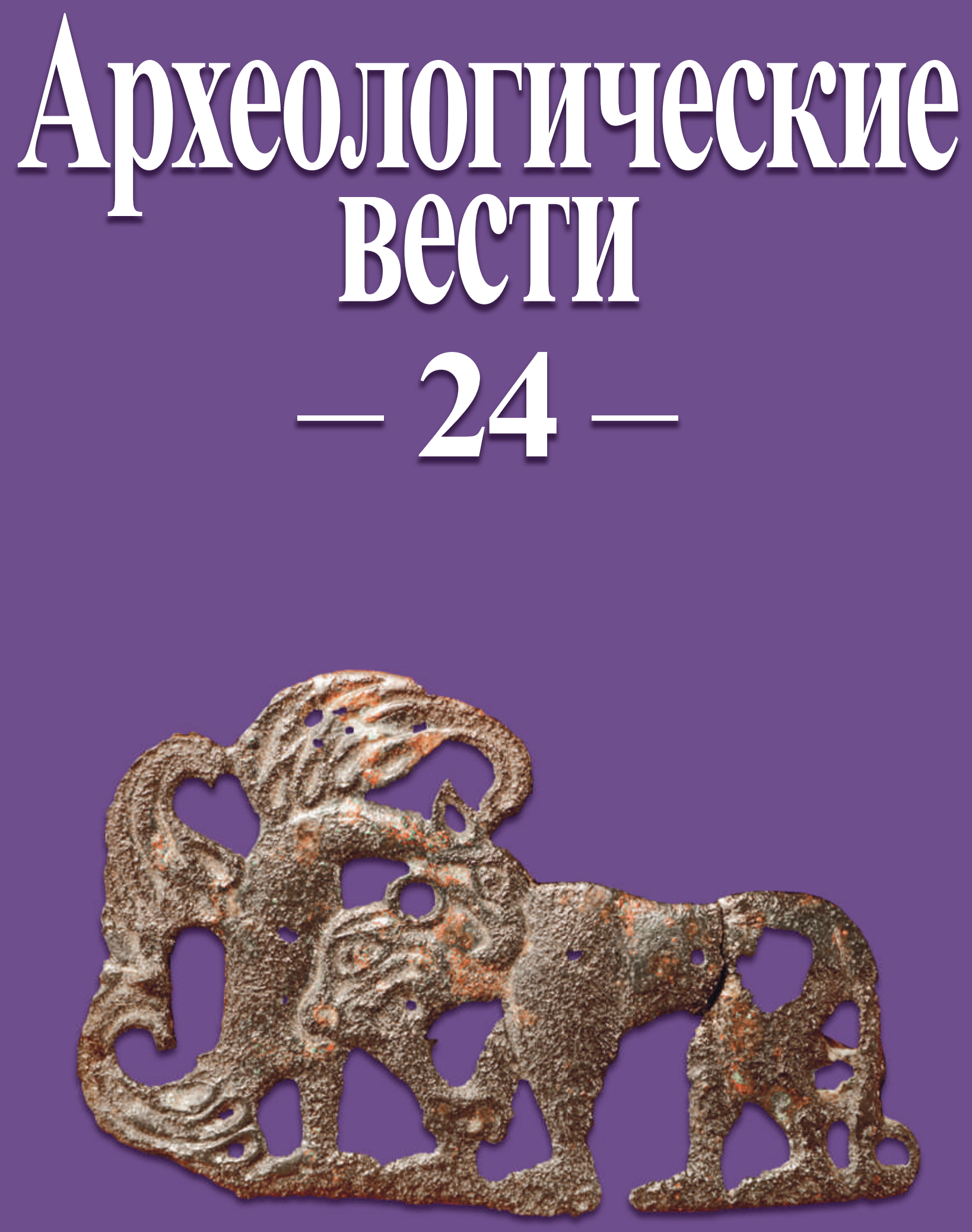


\author{
РОССИЙСКАЯ АКАДЕМИЯ НАУК \\ ИНСТИТУТ ИСТОРИИ МАТЕРИАЛЬНОЙ КУЛЬТУРЫ \\ RUSSIAN ACADEMY OF SCIENCES \\ INSTITUTE FOR THE HISTORY OF MATERIAL CULTURE
}

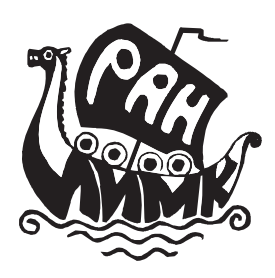




\title{
Archaeological news
}

\author{
24 \\ (2018)
}

SAINT-PETERSBURG 2018 
Археологические вести

\author{
24 \\ (2018)
}

САНКТ-ПЕТЕРБУРГ

2018 
Издание основано в 1992 году

Редакционная коллегия:

член-корреспондент РАН Е. Н. Носов (главный редактор), академик РАН В. Л. Янин, академик РАН Н. А. Макаров,

Н. В. Хвощинская (зам. главного редактора), О. И. Богуславский, М. Ю. Вахтина, Т. С. Дорофеева (отв. секретарь),

М. Т. Кашуба, В. А. Лапшин, Н. Ю. Смирнов, Л. Г. Шаяхметова

Рецензенты:

кандидат исторических наук В. А. Алёкшин

доктор исторических наук С. И. Кочкуркина

Археологические вести, Ин-т истории материальной культуры РАН. - 1992. -

Вып. 24 / [Гл. ред. Е. Н. Носов]. - СПб., 2018. - 428 с., ил.

ISSN 1817-6976

В очередной сборник ежегодника ИИМК РАН включены статьи, посвященные новейшим исследованиям в области археологии, истории и культуры. Впервые вводятся в научный оборот материалы, полученные в результате изучения поселений и погребальных памятников от эпохи камня до средневековья на территории Евразии. В ряде статей рассматриваются конкретные археологические комплексы и отдельные категории материала. В специальный раздел сборника включены работы по актуальным проблемам археологии, касающиеся древностей эпохи бронзы и раннего железа Северного Причерноморья и лесостепной зоны Восточной Европы. В сборнике представлены рецензии на новейшую историко-археологическую литературу и информация о прошедшем в октябре 2017 г. V (XXI) Всероссийском археологическом съезде Отдельный раздел посвящен истории науки. Среди авторов ежегодника ученые из России, Азербайджана, Казахстана, Молдовы, Франции и Германии.

This yearbook of IIMK RAS includes a collection of articles concerned with the most recent researches in the sphere of archaeology, history and culture. It is the first time that some materials obtained through investigation of settlements and burial sites dating from the Stone Age to the Middle Ages in the territory of Eurasia are scientifically published. In a number of the papers, particular archaeological complexes and categories of finds are discussed. A special section of the collection considers works on the urgent problems of archaeology and antiquities of the Bronze Age and Early Iron Age of the Northern Black Sea Region and forest-steppe zone of Eastern Europe. The present collection presents reviews of the latest historical and archaeological publications and information on the 5th (XXIth) All-Russian Archaeological Congress held in October, 2017. A separate section is dedicated to the history of science. Among the authors of this yearbook there are scientists from Russia, Azerbaijan, Kazakhstan, Moldova France and Germany.

Обложка:

Первая страница - Бронзовая пряжка-пластина из кургана № 43 могильника Ала-Тей 1 (к статье М. Е. Килуновской и П. Леуса) First page - Bronze plate/buckle from kurgan no. 43 at the cemetery of Ala-Tey 1 (article by M. E. Kilunovskaya and P. M. Leus)

Четвертая страница - Двор Ладожской крепости. Карта вертикального градиента поля аномалий силы тяжести: а - изолинии вертикального градиента поля аномалий силы тяжести; б - линии геофизических профилей; в - буровые скважины (1989 г.); г- фрагменты разрушенных крепостных стен; д-предполагаемые контуры погребенных развалин каменной кладки, обнаруженные при раскопках А. Н. Кирпичникова (к статье Н. В. Григорьевой, В. В. Кошевого, О. Ю. Медведева)

Fourth page - Courtyard of the Ladoga fortress. Map of the vertical gradient of the field of anomalies of the gravitation force; a - isolines of the vertical gradient of anomalies of the gravitation force; 6 - lines of the geophysical profiles; B - boreholes (1989); $\Gamma-$ fragments of the ruined defensive walls; д - presumed outlines of the buried ruins of the stonework found during A. N. Kirpichnikov's excavations (article by N. V. Grigor'yeva, V. V. Koshevoy \& O. Yu. Medvedev) 


\section{СОДЕРЖАНИЕ}

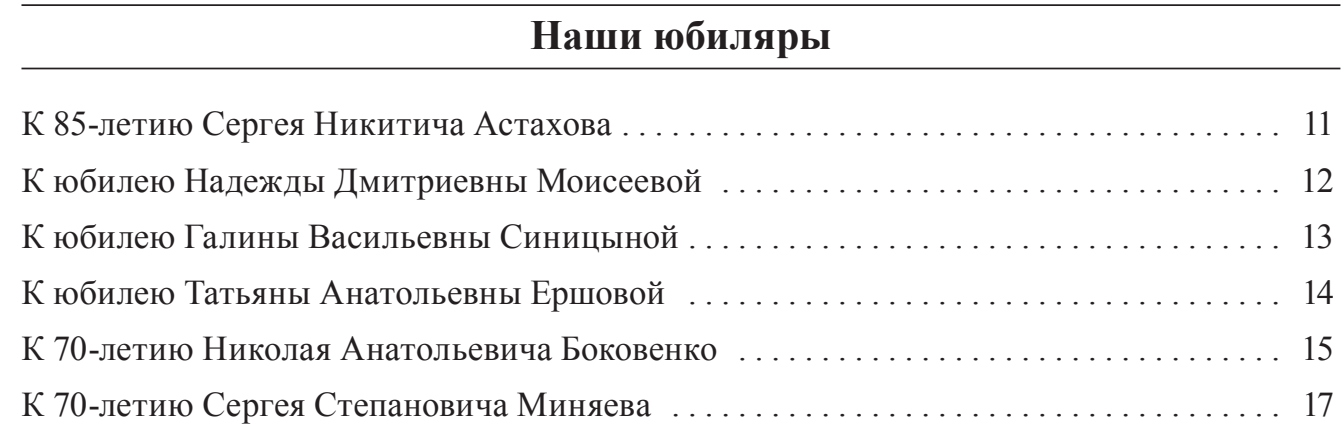

\section{Новые открытия и исследования}

C. А. Кулаков. Раннепалеолитическая стоянка Богатыри/Синяя Балка

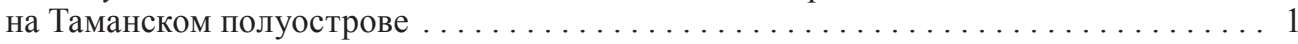

Н. К. Анисюткин, С. А. Кулаков, А. Л. Чепальга. Исследования местонахождений раннего палеолита на высоких морских террасах Южного Крыма в 2016 г. . . . . . . . 33

А. М. Скоробогатов, И. В. Федюнин. Новые материалы палеолита и энеолита на южной границе лесостепного Подонья. . . . . . . . . . . . . . . . . . . . . . 42

C. Н. Разумов. Собака в культовой практике населения Северо-Западного

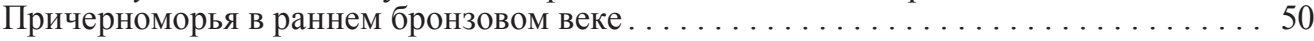

В. А. Трифонов, Н. И. Шиилина, А. Ю. Лобода, Н. Н. Колобылина,

E. Ю. Терещенко, Е. Б. Яцииина. Золотые тонкостенные бесшовные бусы из дольмена раннего бронзового века в кургане № 2 у станицы Царская, СевероЗападный Кавказ: технология изготовления и культурно-исторический контекст . . 68

И. П. Лазаретов, А. В. Поляков. Святилище раннего бронзового века в Туве . . . . 83

В. В. Алейников, В. П. Глебов, В. Я. Стеганцева. Погребение с повозкой эпохи средней бронзы в бассейне реки Деркул в Тарасовском районе

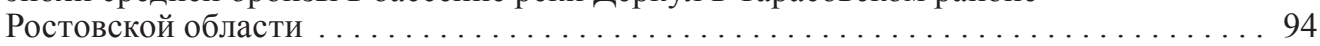

И. А. Кукушкин, Е. А. Дмитриев, А. И. Кукушкин. Каражартас - новый социальностратифицированный некрополь бегазы-дандыбаевской культуры (предварительные результаты исследований) $\ldots \ldots \ldots \ldots \ldots \ldots \ldots \ldots \ldots \ldots$

С. А. Фидельский, М. В. Иващенко, В. С. Синика. Амфорные клейма средиземноморских центров из поселения Чобручи на левобережье Нижнего Днестра . . . . . . . . . . . . . . . . . . . . . . . 110

M. Е. Килуновская, П. М. Леус. Новые материалы улуг-хемской культуры в Туве . . 125

M. М. Казанский. Зооморфные и антропоморфные пряжки и контакты Восточной Прибалтики с Византией в эпоху переселения народов . . . . . . . . . 153

T. А. Кулиев. Из истории монетного двора Дербента . . . . . . . . . . . . . . . . . . 169 
Н. В. Хвощинская. К интерпретации кладов серебряных гривен в Восточной Европе

Н. В. Григорьева, В. В. Кошевой, О. Ю. Медведев. Археолого-геофизические исследования на территории Ладожской крепости (опыт применения метода высокоточной гравиметрии для получения данных о рельефе местности)

M. О. Жуковский. Инструменты для взвешивания с граффити

из раскопок Новгорода . . . . . . . . . . . . . . . . . . . . . . . . . . . . . . . . . . . . . 198

B. В. Яблончук. Топография актовых печатей Новгорода XI-XV вв.

(по материалам Неревского и Троицкого раскопов) . . . . . . . . . . . . . . . 207

П. А. Миляев. Находки деталей ручного огнестрельного вооружения второй половины XV - XVI в. из Старой Ладоги и крепости Орешек в свете восточно- и западноевропейских аналогий $\ldots \ldots \ldots \ldots \ldots \ldots \ldots \ldots$

Л. М. Дмитренко. Результаты исследования керамики поселения Ла-Пайя (провинция Сальта, Северо-Западная Аргентина) из собрания МАЭ РАН . . . . . . 239

\section{Актуальные проблемы археологии}

P. A. Мимоход. Происхождение и семантика фигурных пряжек эпохи бронзы в Европе и на Кавказе в контексте ближневосточных влияний . . . . . . . . . . . 249

М. А. Кулькова, М. Т. Кашуба, А. М. Кульков, Н. С. Власенко, Н. А. Гаврилюк, Э. Кайзер. Первые исследования белой пасты для инкрустации керамики раннего железного века в Северном Причерноморье . . . . . . . . . . . . . . 276

B. И. Козенкова. Заметки о некоторых аспектах и векторе развития кобано-скифских взаимоотношений 290

\section{Обзоры и рецензии}

Попытка с негодными средствами, или Непреодоленное непостижимое

Winkler-Horaček L. Monster in der frühgriechischen Kunst. Die Überwindung des Unfassbaren (Image \& Context. Vol. 4. / Ed. F. Lissarrague, R. Schneider \& R. R. R. Smith) Berlin; Boston: De Gruyter, 2015. -

ISBN: 978-3-11-018900-1. - 690 S. 241 Abb. (Рец. И. Ю. Шауба)

Новые подходы к изучению культурного процесса в Восточной Европе

Élite ou Égalité: Северная Русь и культурные трансформации

в Европе VII-XII вв. / отв. ред. Н. И. Платонова. СПб.: Изд. дом «Бранко»,

2017. - ISBN 978-5-903521-50-0 - 310 с. (Рец. А. И. Саксы ) . . . . . . . . . . . . 321

Этноконфессиональный иллюстрированный атлас Ленинградской области

Этноконфессиональный иллюстрированный атлас Ленинградской области /

О. М. Фишман, М. Л. Засецкая, Г. А. Исаченко, Л. В. Королькова,

О. А. Красникова, А. И. Терюков и др. СПб.: ИД «Инкери», 2017.

ISBN 978-5-903562-79-4 - 656 с. (Рец. В. А. Лапшина)

\section{Сотрудничество Восток - Запад}

С. А. Васильев. V (XXI) Всероссийский археологический съезд (Барнаул-Белокуриха, 1-8 октября 2017)

Э. Кайзер, М. Т. Кашуба, О. Н. Щеглова. Первая Международная конференция «Время и материальность: Периодизация и региональная хронология перехода от бронзового к железному веку в Евразии (1200-600 ВСЕ)»

(Берлин, 19-21 марта 2018 г.) 


\section{История науки}

Е. Г. Застрожнова. К истории изучения античного наследия Крымского полуострова в начале $1920-$ х гг. . . . . . . . . . . . . . . . . . . . . . 339

A. В. Курбатов. История изучения кожевенного дела средневековой Руси .. . . . 349 А. А. Пескова, И. В. Антипов, Д. Д. Ёлиин, К. А. Михайлов, А. Е. Мусин. Археология красоты: опыт творческой биографии Марианны Малевской . . . . 358 Список научных трудов Марианны Владимировны Малевской-Малевич

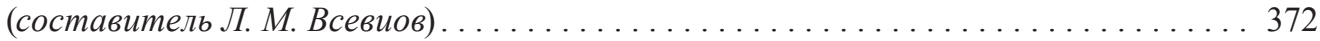

\section{Персоналии}

M. Е. Мазуренко. Лев Михайлович Всевиов . . . . . . . . . . . . . . . . . . . . . .377

Л. М. Всевиов. Издательская деятельность Императорской Археологической комиссии ................................... 383

Ю. А. Виноградов. Последнее письмо академика С. А. Жебелёва . . . . . . . . . . . . .401

Ю. А. Виноградов, И. Ю. Шауб. Разбирая архив В. И. Денисовой . . . . . . . . . . . .405

Ю. А. Виноградов. Два письма из личного архива В. И. Денисовой . . . . . . . . . . .411

\section{Хроника}

C. А. Васильев. Памяти Василия Прокофьевича Любина (1918-2018) 


\section{Content}

\section{Our jubilees}

To the $85^{\text {th }}$ anniversary of Sergey Nikitich Astakhov $\ldots \ldots \ldots \ldots \ldots \ldots \ldots \ldots \ldots$

To the jubilee of Nadezhda Dmitrievna Moiseeva. . . . . . . . . . . . . . . 12

To the jubilee of Galina Vasil'yevna Sinitsyna . . . . . . . . . . . . . . . . . . . 13

To the jubilee of Tat'yana Anatol'yevna Ershova. . . . . . . . . . . . . . . . . 14

To the $70^{\text {th }}$ anniversary of Nikolay Anatol'yevich Bokovenko $\ldots \ldots \ldots \ldots \ldots \ldots$

To the $70^{\text {th }}$ anniversary of Sergey Stepanovich Minyaev $\ldots \ldots \ldots \ldots \ldots \ldots \ldots$

\section{New discoveries and studies}

S. A. Kulakov. Early Palaeolithic site of Bogatyri/Sinyaya Balka on the Taman Peninsula . . . . . . . . . . . . . . . . . . . . . . . . . . . . . . . . . . . . . 19

N. K. Anisyutkin, S. A. Kulakov, A. L. Tchepalyga. Studies of Early Palaeolithic sites on the high marine terraces of Southern Crimea in $2016 \ldots \ldots \ldots \ldots \ldots \ldots \ldots$

A. M. Skorobogatov, I. V. Fedyunin. New Palaeolithic and Eneolithic materials from the southern border of the Forest-Steppe Don region . . . . . . . . . . . . . 42

S. N. Razumov. Dog in Ritual Practice of the North-Western Black Sea

Population of the Early Bronze Age. .......................... 50

V. A. Trifonov, N. I. Shishlina, A. Yu. Loboda, N. N. Kolobylina,

E. Yu. Tereshchenko, E. B. Yatsishina. Gold thin-walled seamless beads from a dolmen of the Early Bronze Age in kurgan no. 2 near the Cossack village of Tsarskaya, Northwestern Caucasus: the technology of manufacturing

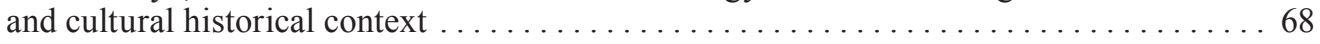

I. P. Lazaretov, A. V. Polyakov. Sanctuary of the Early Bronze Age in Tuva . . . . . . . . 83

V. V. Aleynikov, V. P. Glebov, V. Ya. Stegantseva. Burial of the Middle Bronze Age with a cart in the basin of the Derkul River in Tarasovsky District of Rostov Oblast . . . 94

I. A. Kukushkin, E. A. Dmitriev, A. I. Kukushkin. Karazhartas or a new socially stratified necropolis of the Begazy-Dandybay culture (preliminary results of researches) . . . . . 102

S. A. Fidelskiy, M. V. Ivashchenko, V. S. Sinika. Amphora stamps of Mediterranean centres from the site of Chobruchi on the left bank of the Lower Dniester . . . . . . . 110

M. E. Kilunovskaya, P. M. Leus. New evidence on the Ulug-Khem culture in Tuva . . . 125

M. M. Kazanskiy. Zoomorphic and anthropomorphic buckles and contacts of Eastern Baltic region with the Byzantine Empire in the Great Migration period . . . 153

T. A. Kuliev. From the history of the Derbent mint ...................... 169 
N. V. Khvoshchinskaya. Interpretation of hoards of silver neck rings

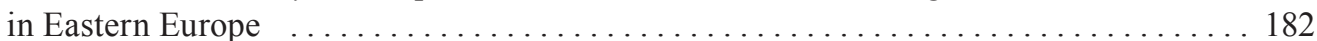

N. V. Grigor'yeva, V. V. Koshevoy, O. Yu. Medvedev. Geophysical archaeological investigations in the territory of the Ladoga fortress (experiment on application of the method of high precision gravimetry

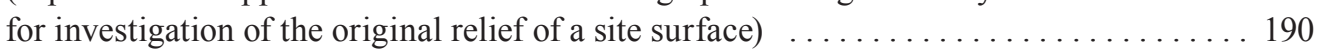

M. O. Zhukovskiy. Weighing instruments with graffiti from excavations in Novgorod ... 198

V. V. Yablonchuk. Topography of official seals in Novgorod of the $11^{\text {th }}-15^{\text {th }}$ century (finds from the Nerevsky and Troitsky excavations) $\ldots \ldots \ldots \ldots \ldots \ldots \ldots \ldots \ldots . \ldots \ldots$

P. A. Milyaev. Finds of parts of hand firearms of the second half of the $15^{\text {th }}-16^{\text {th }}$ century from Staraya Ladoga and the fortress of Oreshek in the view of East- and West-European parallels

L. M. Dmitrenko. Results of the investigation of pottery from the settlement of La Paya (Salta Province, Northwestern Argentina) from the collection of the Museum of Anthropology and Ethnography RAS 239

\section{Topical Problems of Archaeology}

R. A. Mimokhod. The origin and semantics of figured buckles from Bronze Age Europe and Caucasus in the context of Near Eastern influences ................ 249

M. A. Kul'kova, M. T. Kashuba, A. M. Kul'kov, N. S. Vlasenko, N. A. Gavrilyuk,

E. Kaiser. First investigations of white paste for inlaid ceramics of the Early Iron Age from the northern Black Sea littoral . . 276

V. I. Kozenkova. Essay on some aspects and the vector of development of Koban-Scythian interrelations

\section{Review Articles and Book Reviews}

An attempt with unfit means or the Unsurmounted inconceivable

Winkler-Horaček L. Monster in der frühgriechischen Kunst. Die Überwindung des Unfassbaren (Image \& Context. Vol. 4. / Ed. F. Lissarrague, R. Schneider \& R. R. R. Smith) Berlin; Boston: De Gruyter, 2015. -

ISBN: 978-3-11-018900-1. - 690 S. 241 Abb. (Rev. by I. Yu. Schaub)

New approaches to studies of the cultural process in Eastern Europe

Élite ou Égalité: Северная Русь и культурные трансформации в Европе VII-XII вв. / отв. ред. Н. И. Платонова. СПб.: Изд. дом «Бранко», 2017. - ISBN 978-5-903521-50-0 - 310 c. (Rev. by A. I. Saksa)

Illustrated ethno-confessional atlas of Leningrad Oblast

Этноконфессиональный иллюстрированный атлас Ленинградской области /

О. М. Фишман, М. Л. Засецкая, Г. А. Исаченко, Л. В. Королькова, О. А. Красникова,

А. И. Терюков и др. СПб.: ИД «Инкери», 2017. ISBN 978-5-903562-79-4 - 656 с.

(Rev. by V. A. Lapshin) . ......................................... 325

\section{The East-West Cooperation}

S. A. Vasil'yev. The $\mathrm{V}^{\text {th }}$ (XXI) All-Russian archaeological congress

(Barnaul-Belokurikha, October 1-8, 2017) 
E. Kaiser, M. T. Kashuba, O. A. Shcheglova. $1^{\text {st }}$ International conference «Time and materiality: Periodization and regional chronologies at the transition from Bronze to Iron Age in Eurasia (1200-600 BCE)» (Berlin, 19-21 March 2018)

\section{History of Science}

E. G. Zastrozhnova. History of the study of the ancient heritage in the Crimean Peninsula in the early 1920s

A. V. Kurbatov. History of studies of leather tanning in mediaeval Rus

A. A. Peskova, I. V. Antipov, D. D. Yolshin, K. A. Mikhaylov, A. E. Musin.

The archaeology of beauty: essay on the creative biography of Marianna Malevskaya . . 358

List of scientific works of Marianna Vladimirovna Malevskaya-Malevich

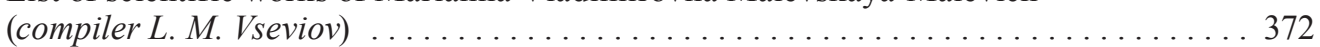

\section{Personalia}

M. E. Mazurenko. Lev Mikhaylovich Vseviov. . . . . . . . . . . . . . . 377

L. M. Vseviov. The publishing activities of the Imperial Archaeological Commission. . . 383

Yu. A. Vinogradov. The last letter of the Academician S. A. Zhebelyov . . . . . . . . 401

Yu. A. Vinogradov, I. Yu. Schaub. Examining the archives of V. I. Denisova ... . . . . 405

Yu. A. Vinogradov. Two letters from V. I. Denisova's personal archives . . . . . . . . . .411

\section{Chronicle}

S. A. Vasil'yev. In memory of Vasily Prokofievich Lubin (1918-2018) . . . . . . . . . . 421

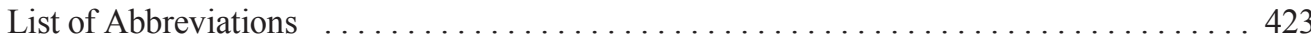




\title{
ЗАМЕТКИ О НЕКОТОРЫХ АСПЕКТАХ И ВЕКТОРЕ РАЗВИТИЯ КОБАНО-СКИФСКИХ ВЗАИМООТНОШЕНИЙ
}

\author{
В. И. Козенкова ${ }^{1}$
}

Аннотация. В связи с 80-летием раскопок Е. И. Крупновым памятников кобанской культуры (Алхасте, Нестеровская) в Ассинском ущелье Северного Кавказа в статье вновь поднимается вопрос о взаимоотношениях автохтонной культуры с кочевой культурой собственно скифов, элементы которой были выявлены в этих памятниках. Новые данные позволяют охарактеризовать различные мнения об основных аспектах и векторе развития кобано-скифских взаимоотношений в VII-IV вв. до н. э. Приводятся примеры трансформации кобанской культуры на позднем этапе развития, ее степени и глубины в зависимости от близости и удаленности от границы контактов двух сообществ в условиях наличия широкого ареала коренной культуры. Затронут хронологический аспект. Выявлены противоречия в версиях специалистов относительно формы и модели взаимоотношений. Автором предложена модель устной договоренности в форме вооруженного нейтралитета, как наиболее адекватно отвечающая имеюшимся археологическим свидетельствам.

Annotation. This sketch is connected with the 80th anniversary of E. I. Krupnov's excavations of sites ofthe Koban culture (Alkhaste, Nesterovskaya) in the Assa River Gorge of the Northern Caucasus. Here the question is once again raised about the interrelations between the autochthonous culture and the nomadic culture of the Scythians proper. Elements of the latter culture were distinguished at the abovementioned sites. On the basis of the new evidence accumulated, different opinions are characterized about the main aspects and the vector of development of the Koban/Scythian interrelations in the $7^{\text {th }}-4^{\text {th }}$ century BC. The causes of the transformation of the Koban culture, the extent and depth of this transformation depending on the closeness or remoteness from the border of the contacts of the two communities in the conditions of the presence of a wide habitat of the indigenous culture are here considered. The chronological aspect is also touched upon. Opposing versions by different experts concerning the form and model of the interrelations are shown. The present author proposes a model of a verbal agreement in the form of armed neutrality as the most adequately responding to the archaeological evidence available.

Ключевые слова: Северный Кавказ, Е. И. Крупнов, кобанская культура, позднекобанская культура, скифская культура, контактирующие сообщества, вооруженный нейтралитет.

Keywords: North Caucasus, E. I. Krupnov, Koban culture, Late Koban culture, Scythian culture, contacting communities, armed neutrality.

DOI: $10.31600 / 1817-6976-2018-24-290-310$

Тысячелетнее существование кобанской культуры в окружении инокультурного мира вносило в жизнь автохтонного населения обстоятельства, обусловленные исторически (кратковременные связи, военные набеги, миграции и т. п.). Большая роль во всех этих процессах принадлежала кочевым культурам юга Восточной Европы. Такие контакты приводили к существенной трансформация многих аспектов автохтонной культуры под воздействием чуждых культурных элементов. В данном процессе

\footnotetext{
${ }^{1}$ Россия, 117036, г. Москва, ул. Д. Ульянова, 19. Институт археологии РАН, Отдел скифо-сарматской археологии. E-mail: kozenkova_vi@mail.ru.
}

исключительную роль играли кочевые племена скифов, господствовавшие в Предкавказье в эпоху их походов в Переднюю Азию и возврата оттуда (VII-IV вв. до н. э.). Накопленные с момента открытия кобанских древностей данные по многим сторонам быта носителей культуры позволяют уверенно говорить о появлении на позднем этапе ее развития качественно новых форм посуды и их большем разнообразии, новых типов украшений, железного оружия, часть которого была либо явно скифского типа, либо ему подражавшего (наконечники стрел, кинжалы). Конское снаряжение преимущественно подражало степным формам. 
Значительное скифское влияние испытали детали костюма, выполненные в зверином стиле. Ряд кочевнических образов звериного стиля был преобразован согласно вкусам местного населения, выступая в иной ипостаси. Несмотря на традиционный оседлый образ жизни населения кобанской культуры, новые, связанные с кочевой культурой элементы проявились даже в погребальном обряде: вытянутая поза захоронений покойников, реальгар в погребальном инвентаре, брахикранность некоторых черепов, захоронения коня.

При изучении столь заметных явлений в кобаноскифских взаимоотношениях исследователи выделяют несколько аспектов, из которых главными, на мой взгляд, являются: 1) причины трансформации кобанской культуры на поздних этапах; 2) степень и глубина трансформации; 3) проблема этнополитического сосуществования двух различных культур; 4) хронологический аспект - вектор развития кобано-скифских взаимоотношений от их начала и до конца. В историографии существуют разные гипотезы, часть которых получила подтверждения новыми находками, часть - потеряла свою актуальность. Однако многое все еще остается предметом дискуссии.

Стоит напомнить о произошедших значительных изменениях во взглядах по многим обозначенным выше направлениям. В 30-е гг. XX в. в археологической науке господствовала стадиальная система, согласно которой археологические материалы Северного Кавказа делились на группы, соответствующие развитию экономического и социального строя. В результате и автохтонные, и подвергшиеся скифскому влиянию памятники относились к так называемой скифской стадии. Наиболее определенно в те годы по поводу этой схемы высказался А. А. Иессен. Анализируя добытые материалы Моздокского могильника, в которых прослеживались скифоидные элементы, он писал: «необходимо еще раз отметить, что применение термина «скифский» и здесь и в дальнейшем изложении является условным. Им обозначается стадиальное состояние данной общественной среды, более или менее общее для весьма обширных территорий от лесостепной полосы на севере до предгорий Кавказа на юге. Говорить об этническом единстве насельников Предкавказья и собственно "скифов" Север- ного Причерноморья затруднительно. Нет также оснований считать, что местное население в Закубанье и на Тереке носило имя скифы» (Пиотровский, Иессен, 1940. С. 28, сн. 2) (курсив мой. $B$. K.). Изучая имевшиеся на то время немногочисленные материалы из Кабардино-Балкарии (Каменномостский могильник и др.), исследователь различал «два различных комплекса - степной, отвечающей собственно "скифской" культуре, с одной стороны, предгорный и горный, теснейшим образом связанный с предшествующим этапом...» (Иессен, 1941. С. 20).

С начала $30-\mathrm{x}$ гг. XX в. с появлением материалов из стационарно раскопанных памятников была предложена другая интерпретация причин изменения отдельных элементов автохтонной культуры. Согласно этой гипотезе имело место столкновение двух разных по происхождению культур: местной и кочевой, агрессивно милитаризованной, скифской. Речь идет о раскопках Е. И. Крупнова Алхастинского поселения и археологического комплекса Нестеровского поселения и могильника в Ассинском ущелье в Ингушетии на Северном Кавказе (рис. 1, 1-13). Основанием для гипотезы послужил комплекс находок (сосуды баночной формы, украшенные налепным щипковым орнаментом по краю венчика, бронзовые наконечники стрел скифского типа, железный акинак и другие, менее яркие предметы) из позднего слоя этих поселений кобанской культуры и в могильнике. На основе их анализа и близких аналогий он попытался «установить органическую связь Нестеровского могильника с подлинной скифской культурой» (Крупнов, 1948. C. 28) и сформулировал заключение о том, «что в определенный период бытования кобанской культуры на Северном Кавказе выявляются новые археологические объекты, представляющие иную культуру, именуемую скифской» (Там же. С. 31). Несмотря на скептицизм со стороны специалистов-скифологов (см.: Крупнов, 1960. С. 356), исследователь придерживался мнения, что выявленные элементы не позволяют такие памятники Ассинского ущелья «рассматривать изолированно от памятников Скифии», и они могут «считаться пограничными представителями, отражающими скифскую культуру» (Крупнов, 1941. С. 182). По мере накопления новых материалов свои 


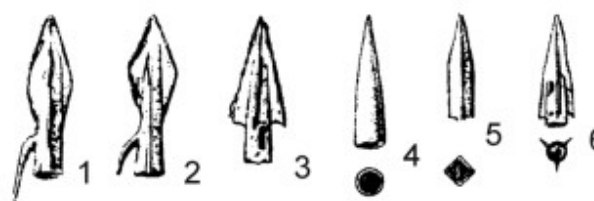

a 1.4
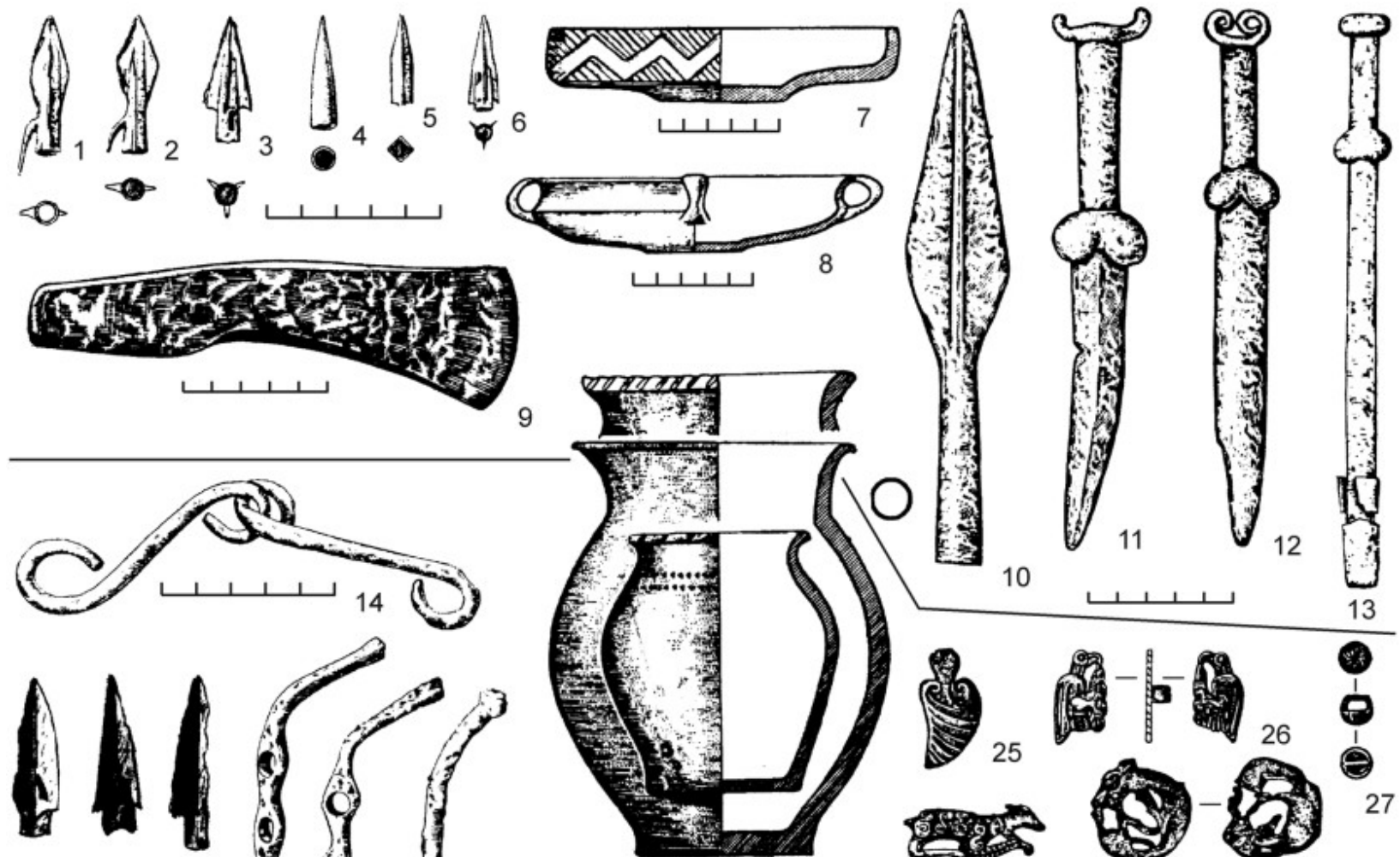

$\begin{array}{lll}15 & 16 & 17\end{array}$
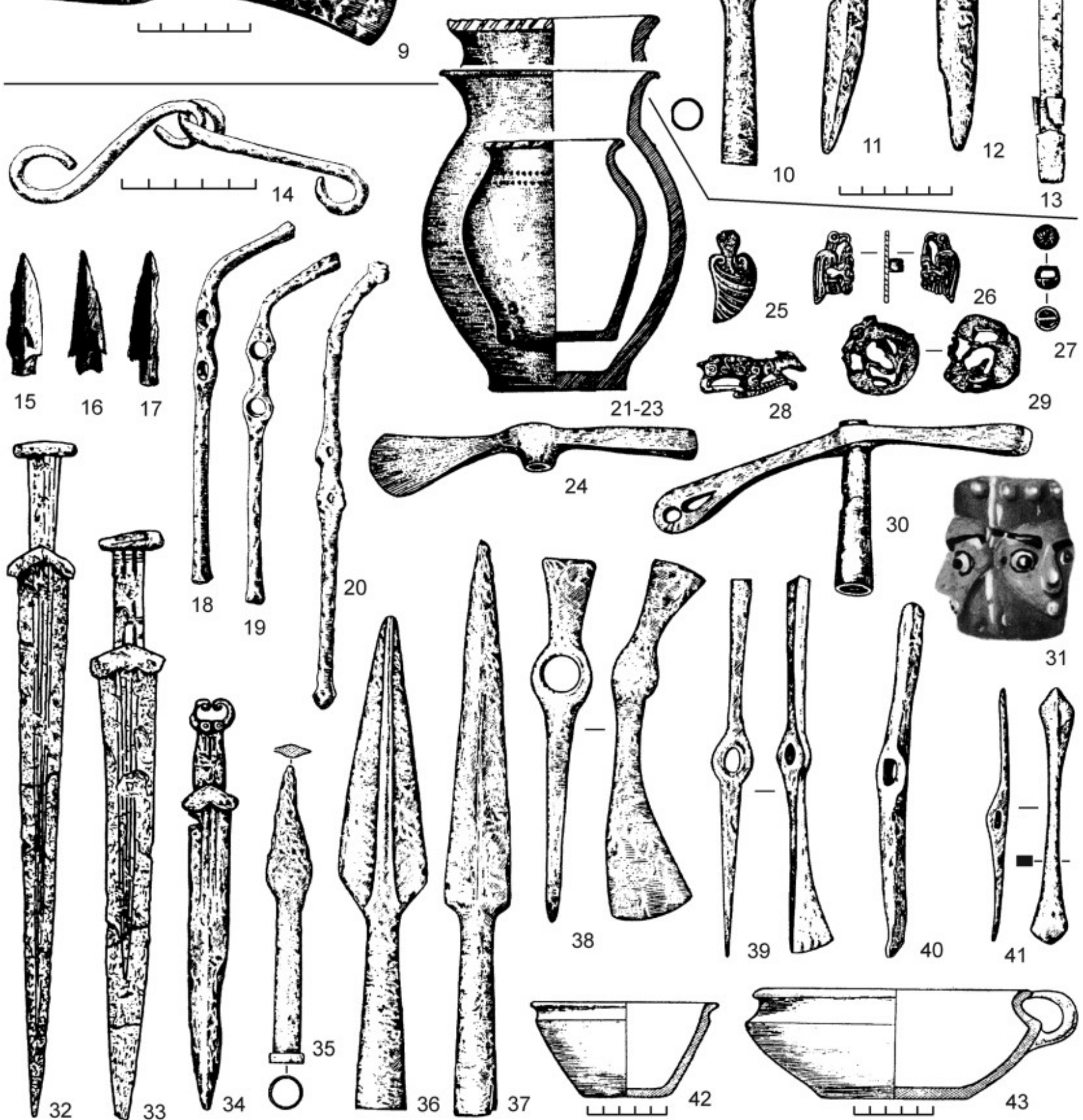
предварительные выводы ученый углубил, уточнил (Крупнов, 1949. С. 27) и скорректировал некоторые излишне прямолинейные заключения.

В своем основополагающем исследовании «Древняя история Северного Кавказа» Е. И. Крупнов (1960) представил версию о трех вариантах, выделенных в ареале кобанской культуры к концу 50-х гг. $\mathrm{XX}$ в., фундаментально подкрепленную новыми материалами (Луговой могильник), одновременно предложив убедительную концепцию трансформации кобанской культуры в середине VII - IV в. до н. э. Она сводилась к тому, что в результате скифских походов через Кавказ в Переднюю Азию во всех культурах Кавказа, в том числе и в кобанской, явственно активизировались скифские элементы, глубоко затронув местные культуры. «Проникновение северных элементов привело к некоторому культурному синкретизму в отдельных районах Кавказа. < ..> смешанный характер вещевого могильного инвентаря, а в какой-то степени и погребального обряда, наблюдаемого в Нестеровском и типологически близких ему других могильниках центральной полосы Северного Кавказа, совершенно очевиден. Следовательно, эта особенность памятников раннескифского времени составляет уже их типическую черту, безусловно, отражающую какую- то историческую реальность, а также то соотношение различных элементов, которые оформляли культуру и этнографическую физиономию местного общества» (Крупнов, 1960. С. 385). На основе имевшихся источников Е. И. Крупнов не только подчеркивал наличие в позднекобанских памятниках культурного синкретизма, но и предполагал возможность не временного пребывания здесь скифов, a «частичного их оседания в отдельных пунктах». Специально при этом указывалось, что полной замены местной культуры с появлением в ней элементов кочевой не произошло. Местная культура оказалась «живучей», по выражению ученого, в силу ее укорененности (Там же. С. 388 и сл.). Отмечая важность существовавших взаимосвязей Скифии и Кавказа, Е. И. Крупнов особо обращал внимание на то, что «при разработке этого вопроса необходимо учитывать факт первого появления скифских вещей и дальнейшее, уже местное их производство по скифским образцам» (Крупнов, 1955. С. 11) (курсив мой. $-B . K$.). Другими словами, эти вещи должны были соответствовать вкусам и традициям автохтонного населения.

Наиболее яркие примеры такого усвоения населением позднекобанской культуры новых чуждых (степных) элементов представлены на северном

Рис. 1. Материалы скифского типа в позднекобанских памятниках ущелья р. Ассы.

1-13 - Нестеровский могильник VII-VI вв. до н. э.: 1-4 - погребение № 20; 5, 12 - погребение № 12; 6 - погребение № 4; 7 - погребение № 2; 8 - погребение № 50; 9 - вне погребения; 10 - кол. Арчакова; 11 - погребение № 1; 13 - погребение № 53;

14-43 - Луговой могильник VI-IV вв. до н. э.: 14, 18-19, 30, 40 - погребение № 50; 15-17, 27-29, 34,

41-42 - погребение № 64/128; 20, 31, 37 - погребение № 48/112; 21-23 - сосуды скифского типа в могильниках ущелья p. Ассы; 24 - погребение № 32/96; 26 - погребение № 66/130; 33 - погребение № 49/113; 35 - погребение № 26/90; 32, 36 - погребение № 37/101; 38, 43 - погребение № 88/152.

1-6-Крупнов, 1948. С. 25, рис. 22; 7, 8, 42, 43 - Козенкова, 1982. С. 174, табл. LIII; 4, 8-10; 9, 12, 13,35 - Крупнов, 1960. C. 177, 277, 482, 483, рис. 21, 5; 45; табл. LXII, 1; LXIII; 10, 11 - Крупнов, 1941. С. 196, табл. V; 4, 7; 14 -20, $24-37$, 40-41-Мунчаев, 1963. С. 146, 151, 153, 161, 170, 171, 173, 180, 186, рис. 4, 6; 7, 1; 13, 5, 6, 9, 10; 18, 5; 19, 9, 10; 20, 3-6; 26, 3, 8,$12 ; 29,6-9,13,14,16 ; 21-23$ - реконструкция автора сосудов из Нестеровского и Лугового могильнико.

1-3, 15-17, 25-29- бронза; 21-23, 42, 43 - глина; 31 - цветное стекло; остальное - железо

Fig. 1. Finds of the Scythian type from Late Koban sites in the gorge of the Assa River.

$1-13$ - Nesterovskoye burial ground of the $7^{\text {th }}-6^{\text {th }}$ century BC: $1-4$ - burial no. $20 ; 5,12$ - burial no. $12 ; 6$ - burial no. 4 ; 7 - burial no. 2; 8-burial no. 50; 9 - from outside a burial; 10 - Archakov's collection; 11 - burial no. 1; 13 - burial no. 53;

14-43 - Cemetery of Lugovoy of the 6th-4th century BC: 14, 18-19, 30, 40 - burial no. 50; 15-17, 27-29, 34, 41-42 - burial no. $64 / 128 ; 20,31,37$ - burial no. 48/112; 21-23 - pots of the Scythian type from cemeteries of the Assa gorge; 24 - burial no. $32 / 96 ; 26$ - burial no. 66/130; 33 - burial no. 49/113; 35 - burial no. 26/90; 32, 36 - burial no. 37/101; 38 , 43 - burial no. 88/152. 1-6 - Крупнов, 1948. Р. 25, Fig. 22; 7, 8, 42, 43 - Козенкова, 1982. Р. 174, Pl. LIII; 4, 8-10; 9, 12, 13, 35 - Крупнов, 1960. Р. 177, 277, 482, 483, Fig. 21, 5; 45; Pl. LXII, 1; LXIII; 10, 11 - Крупнов, 1941. P. 196, Pl. V; 4, 7; 14 -20, 24-37, 40-41-Мунчаев, 1963. P. $146,151,153,161,170,171,173,180,186$, Fig. 4, 6; 7, 1; 13, 5, 6, 9, 10; 18, 5; 19, 9, 10; 20, 3-6; 26, 3, 8, 12; 29, 6-9, 13, 14, 16; 21-23 - author's reconstruction of the pottery from the cemeteries of Nesterovskoye and Lugovoy)

1-3, 15-17, 25-29- bronze; 21-23, 42, 43 - clay; 31 - coloured glass; the rest - iron 
склоне Кавказа в погребальном инвентаре Лугового могильника VI-IV вв. до н. э. (рис. 1, 15-43) (Мунчаев, 1963. С. 139 и сл.). Среди комплексов вещей более 150 погребений ярко выделяются инвентари могил с массово представленным оружием разных типов и конским снаряжением, изготовленными во многом по скифским и позднее - по савроматским образцам, однако почти не имеющими прямых аналогий из ареала собственно кочевых культур. Некоторые погребения отличаются очевидными импортными престижными изделиями. Так, в погребении № 64/128 (рис. 1, 15-17, 27-29, 34, 41, 42) среди высокохудожественных украшений присутствуют собственно скифские предметы и их подражания: немногочисленный набор бронзовых трехгранных втульчатых наконечников стрел, железный акинак с навершием в виде волют, бляшки в виде крыла птицы, стилизованная бляшка в форме свернувшегося хищника, фрагмент бронзового пояса с гофрированной в «елочку» поверхностью, напоминающей визуально наборные пластинчатые скифские портупейные пояса (Козенкова, 2013. С. 119, рис. 62, 7). Кроме того, имеются наборы из импортных цветных стеклянных бус, среди которых выделяются крупные экземпляры с лицом человека (рис. 1, 31). Бляшка в виде свернувшегося зверя скорее представляет местную копию собственно скифских изделий (Мунчаев, 1963. С. 187, рис. 29, 16, 17; Козенкова, 1982. С. 31, табл. XXI, 9, 10). В погребении № 66/130 к таким вещам, безусловно, относятся бронзовые уздечные бляшки в виде орла, клюющего рыбу, и ожерелья из стеклянных бус (Мунчаев, 1963. С. 151, рис. 7, 1, 2; Козенкова, 1982. С. 31, табл. XXI, 11). Среди бытовых предметов и особенно аксессуаров костюма отмечены изделия, истоки формы которых (например, бронзовые двуховальные бляхи и бронзовые поясные пряжки с кругами) свидетельствуют о западноевропейском происхождении. Их прототипы прослеживаются в ареале позднего Гальштатта (VI-V вв. до н. э.), причем как особый набор украшений, так и схема их расположения в парадном костюме погребенных в Гальштаттском могильнике (Козенкова, 2007; 2013. Рис. 17, 5; цветная вклейка $17 \mathrm{a}, 37,78)$. Подобное сходство вряд ли возможно без визуального наблюдения, что свидетельствует о миграционных импульсах поздних «кобанцев» в Западную Европу и, возможно, в Крым, где в син- хронных с кобанскими могильниках обнаружены сходные украшения (Лесков, 1965. С. 148, рис. 38; Козенкова, 2008. С. 75). Включение собственно скифских вещей в инвентари погребенных в Луговом могильнике отражает не только явно элитарный характер захороненных, но и их воинскую мобильность. Миграционные импульсы «кобанцев» отмечены в этот период на восток в сторону Поволжья, в ареал савроматов. Доказательствами служат находки в позднем слое Сержень-юртовского поселения бронзовых втульчатых наконечников стрел кочевников. Так, в развале позднекобанского помещения № 4 обнаружена втульчатая трехгранная стрела конца VII - VI в. до н. э. (Козенкова, 2001. С. 84, рис. 45,2$)$. Второй бронзовый втульчатый трехлопастный наконечник с изображением змейки на лопасти (Там же. С. 83 , рис. 85,15 ) аналогичен найденным экземплярам в савроматских погребениях конца VI - V в. до н. э., например, в Блюменфельдском кургане № $\mathrm{A} 12$ (Смирнов, 1964. С. 303 сл., рис. 11Б, 4). Чрезвычайно важное свидетельство существования прямых контактов поздних «кобанцев» с Поволжьем - две бронзовые ажурные уздечные бляхи из Галайтинского могильника в ущелье p. Аксай в Чечне. Эти четырехлучевые розетки свастической схемы с орлиными головками на концах имеют не просто прямые параллели, а идентичны уздечным бляхам из Хошеутовского могильника V в. до н. э. в Северном Прикаспии (Багаев, 2008. С. 79 , рис. 126,10 ; Козенкова, 2013. С. 128, рис. 71 , $10,11,23)$. Все вышеприведенные примеры, скорее всего, могут свидетельствовать о самостоятельном, нейтральном сосуществовании сообществ, основанном не только на силовом превосходстве со стороны скифского контингента, но и на других факторах. Видимо, сразу после внезапного устрашающего нашествия, главным образом в конце VI - начале IV в. до н. э., пришельцы стали нуждаться в экономических и военных ресурсах коренного населения, что требовало совершенно другой системы взаимоотношений.

Подобные сложные, разнохарактерные отношения двух пограничных сообществ как раз и подтверждают многолетние исследования Серженьюртовского комплекса (поселение и могильник), расположенного у входа в ущелье р. Хулхулау в Чечне на востоке ареала кобанской культуры 
(Козенкова, 2001; 2002). Анализ материалов второго этапа обитания поселка-убежища показал, что вначале контакты были агрессивными, когда внезапность и превосходство скифских передовых орд привели к разрушению поселка, гибели защитников и бегству части обитателей в горы (рис. 2, 1-18). Находки ранних бронзовых наконечников стрел скифского типа (рис. 2, 18) свидетельствуют, что эти события могли происходить во второй четверти - середине VII в. до н. э. Однако уже в конце VII - начале VI в. до н. э. обитатели Сержень-юртовского поселения и всей округи возвращаются на старые обжитые места. Возникают прочные межкультурные отношения, судя по упомянутым выше степным наконечникам стрел в слое остатков жилищ второго периода (VI-V вв. до н. э.). Этот процесс наблюдается и на других позднекобанских поселениях, например на Нестеровском.

Подтверждают эту ситуацию и самые поздние погребения Сержень-юртовского могильника. Могилы на его позднем участке содержали железное оружие местных форм (наконечники стрел-площики, топоры), железный кинжал кобанского облика с элементами синкретизма и железные акинаки (Козенкова, 2002. Табл. 22, 7; 71, 14; 75, 14), однако при отсутствии типичных, собственно скифских наконечников стрел (рис. 2, 19-33). Один из железных топоров имеет очертания (рис. 2, 29), аналогичные местным традиционным бронзовым изделиям (Там же. Табл. 71, 15).

Близкие процессы наиболее засвидетельствованы в могильниках обеих групп центрального варианта (Тли, Кливана, Комарово), особенно в пограничной зоне Центрального Предкавказья. Речь идет о грунтовых могильниках конца VI - начала IV в. до н. э. - у сел. Комарово (Северная Осетия), Нижне-Джулатский могильник у г. Майский в Кабардино-Балкарии и курган у ст. Терской. Эти памятники дали ценную информацию о процессе трансформации позднекобанской культуры в результате ее взаимодействия со скифской и савроматской культурами конца VII-IV вв. до н. э. (Абрамова, 1974. С. 195 и сл.). По мнению М. П. Абрамовой, материалы этих памятников, отражая традиционно местный характер культуры, содержали кочевнические изделия. Например, наборы бронзовых наконечников стрел, фрагмент железного однолезвийного кинжала, элементы конской узды и украшений уздечки, близкие кочевым вещам культур скифо-савроматского типа. В Комаровском могильнике (рис. 3, 1-18) особо выделяются костяная головка птицы с загнутым клювом и крупные лощеные орнаментированные корчаги (рис. 3, 10, 20), аналогичные известным в синхронных памятниках Ставрополья еще с конца XIX - начала XX в. (аналогичная ситуация прослежена и по составам бус из ожерелий: цветное стекло, египетский фаянс, янтарь). Для мужских захоронений типичен военизированный характер погребального инвентаря.

Схожие по времени материалы содержит могильник близ ст. Исправная Ставропольского края. В каменных ящиках, расположенных на высокой террасе предгорий на границе со степью, обнаружены захоронения с погребальным инвентарем раннескифского периода, но мало подверженного влиянию культуры скифов. Лишь одно погребение из 14 содержало единичные скифские наконечники стрел, часть из которых с удлиненно ромбическим пером и с шипами на втулках. Ранними формами отличалась и керамика (Козенкова, Найденко, 1980. С. 195 и сл.).

По проблеме причин трансформации кобанской культуры на поздних этапах можно привести множество других примеров, учитывая количество важных (открытых и стационарно раскопанных) позднекобанских памятников после выхода книги Е. И. Крупнова. Это Тлийский и Кливанский могильники, могильник Гастон Уота центрального варианта; Новогрозненский и Пседахский могильники на востоке ареала, могильники Кисловодской котловины - на западе (долго функционировавшие могильники Клин-Яр II и Клин-Яр III, Султангорский 3, Уллубаганалы-2 и др.).

Большое значение для рассматриваемых в статье вопросов имеют материалы курганных могильников в Центральном Предкавказье, среди которых - Красное знамя, Новозаведенное-I, Новозаведенное-II и Новозаведенное-III, относившиеся к культуре собственно скифов и датированные специалистами серединой VII-VI в. до н. э. (Петренко, 2006; Петренко, Маслов, 1996; Петренко и др., 2000; 2006). По мнению большинства скифологов, эти материалы позволили «подтвердить постоянное пребывание степного кочевнического населения на территории 

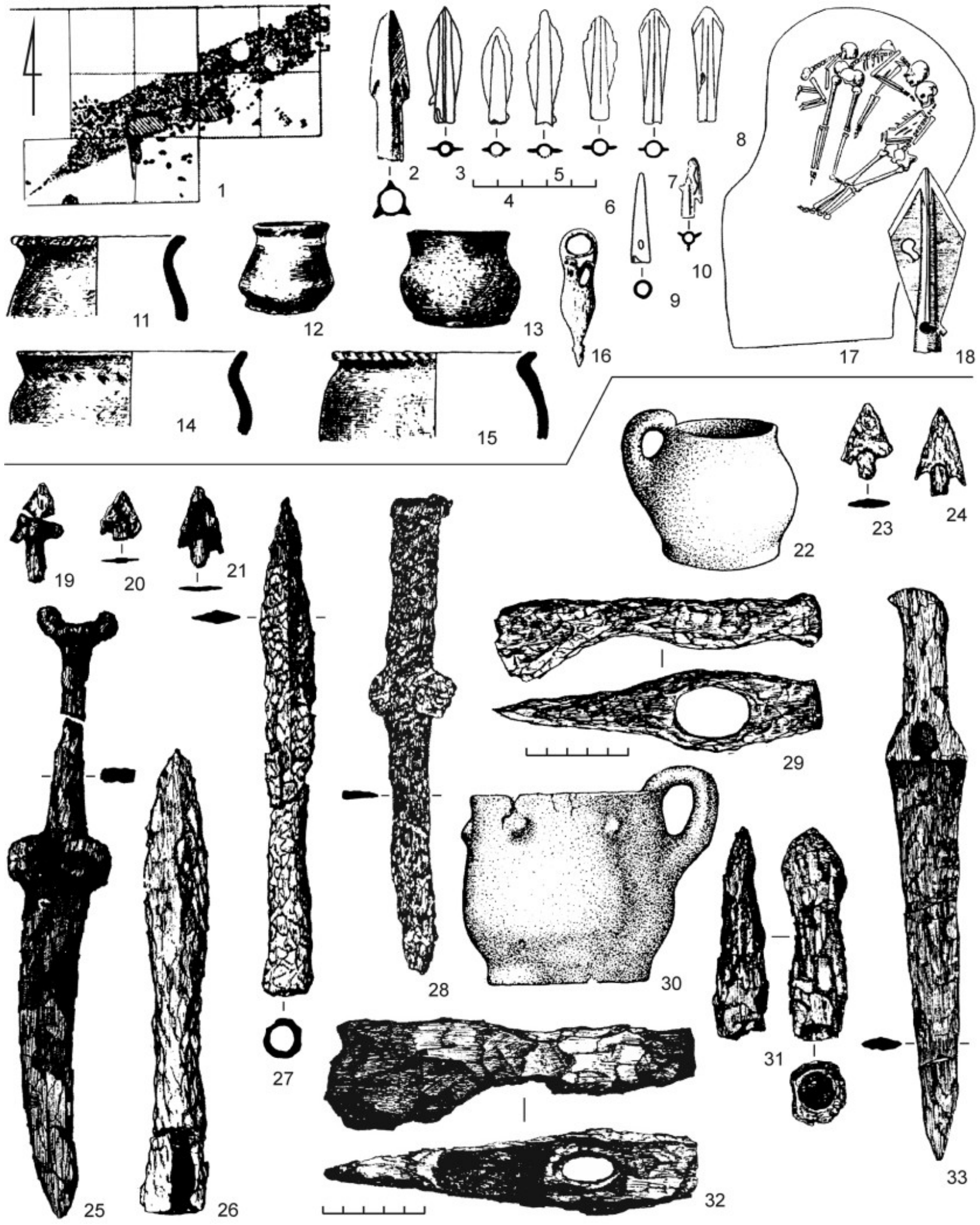
Центрального Предкавказья» и создать здесь плацдарм для переднеазиатских походов (Петренко, 2006. С. 17, 52) (курсив мой. - В. К.). Как полагает В. Г. Петренко, «в период походов степи Северного Кавказа были уже освоены скифами, создавшими здесь политическое объединение с определенной соииальной структурой...» (Там же. С. 120) (курсив мой. $-B . K$.), то есть в регионе было установлено политическое господство скифов. Впрочем, были и альтернативные мнения (Кореняко, 1990; Кузнеиова, 1992; 2015; Козенкова, 1996. С. 143-144).

Предполагаемая в форме постулата политическая ситуация в предгорьях Северного Кавказа не могла не вызвать среди специалистов острую дискуссию по поводу степени и глубины трансформации позднекобанской культуры. Обсуждается и модель долгих взаимоотношений между двумя тесно контактировавшими социумами, не обойден стороной и хронологический аспект. После публикации обобщающего труда Е. И. Крупнова вышли в свет многие десятки статей и важных аналитических монографий (Виноградов, 1972; Ильинская, Тереножкин, 1983; Техов, 1980; 2002; Дударев, 1991; Дударев, Рунич, 1992. С. 22-26, 35-49; Махортых, 1991; Ковалевская, 1984; 2005. С. 43, 66; Мошинский, 2006; и др.). В этих трудах предметно анализировались и кобано-скифские взаимоотношения: на основе новых данных были высказаны разные гипотезы и заключения о характере контактов местного населения с кочевниками в скифский период.

В своей монографии В. Б. Виноградов изложил кардинальные вопросы взаимоотношений насе- ления позднекобанской культуры со скифо-савроматским миром. Проанализировав имеющиеся старые и накопленные новые материалы, исследователь подтвердил и развил точку зрения Е. И. Крупнова о скифском нашествии в ареал кобанской культуры, «познавшей мощь военных мобильных отрядов $<\ldots>$, диктовавших свою власть и волю» (Виноградов, 1972. С. 42, 75), что было основной причиной трансформации местной культуры. По материалам могильников В. Б. Виноградов выделил три хронологических периода в развитии взаимоотношений. Первый - 50 лет VII и 15 лет VI вв. до н. э. - период «покорности и зависимости» местного населения в целом от степняков, но в то же время вовлечение «отдельных родоплеменных групп в тесный альянс со скифами, подразумевающий совместное участие союзников в азиатских походах» (Там же. С. 75, 78) (курсив мой. $-B$. K.). Второй - начало VI в. до н. э. - при «дальнейшем господстве над частью аборигенов» начало возвращения основной массы местного населения из высокогорья, как признак стабилизации обстановки (Там же. С. 79). Третий-VI-V вв. до н. э. «вполне мирный и дружественный характер <..> части племен» (Там же. С. 81). Теперь это уже «зачастую не зависимое население, ищущее защиту у «плетня сильных», а вполне суверенные, боеспособные, готовые к обороне местные племена, чьи отношения друг с другом и соседними степняками строятся по принципу «вооруженного уважения»»» (Там же. С. 84-85) (курсив мой. - В. К.).

Подводя итог сравнительному анализу погребального обряда и инвентаря могил «кобанцев»

Рис. 2. Находки скифского типа в позднекобанских памятниках ущелья р. Хулхулау. 1-18 - поселение Сержень-юрт, холм-убежище 1 , слой VII-V вв. до н. э.: 1 - стратиграфия двух разновременных слоев, часть плана; 2-10 - наконечники стрел; 11-15 - сосуды из позднего слоя; 16 - поделка с элементами скифского звериного стиля; 17 - яма с погребениями; 18 - ранний наконечник стрелы в засыпи ямы с погребениями, край холма; 19-33- могильник Сержень-юрт (раскоп II), VII в. до н. э. (19-22, 25, 26 - погребение № 4; 23, 24, 27-29 - погребение № 1; 30-33 - погребение № 3).

1-18-Козенкова, 2001. С. 150, 188, 195, 196, рис. 45, 1, 2; 86, 8, 11, 13-15; 93; 94, 4, 5; 19-33-Козенкова, 2002. С. 226, 229, 230 , табл. 75, 5-7, 9, 12, 14; 71, 3, 4, 13-15; 74, 16-19.

2-10, 18 - бронза; $11-15,22,30$ - глина; 16 - кость; 33 - железо и кость; остальное - железо

Fig. 2. Finds of the Scythian type from the Late Koban sites in the Khulkhulau River gorge. 1-18-settlement of Serzhen-Yurt, hill shelter 1, layer of the 7th-5th century BC: 1 - stratigraphic scheme of two layers of different periods, part of the plan; 2-10 - arrowheads; $11-15$ - pottery from the later layer; 16 - an article with elements of the Scythian animal style; 17 - pit with burials; 18 - early arrowhead from the fill of the pit with burials, edge of the hill; $19-33$ - cemetery of Serzhen-Yurt (excavation II), 7th century BC (19-22, 25, 26 - burial no. 4; 23, 24, 27-29-burial no. 1; 30-33-burial no. 3).

1-18-Козенкова, 2001. Р. 150, 188, 195, 196, Fig. 45, 1, 2; 86, 8, 11, 13-15; 93; 94, 4, 5; 19-33-Козенкова, 2002. Р. 226, 229, 230, Pl. 75, 5-7, 9, 12, 14; 71, 3, 4, 13-15; 74, 16-19.

2-10, 18 - bronze; $11-15,22,30$ - clay; 16 - bone; 33 - iron and bone; the rest - iron 

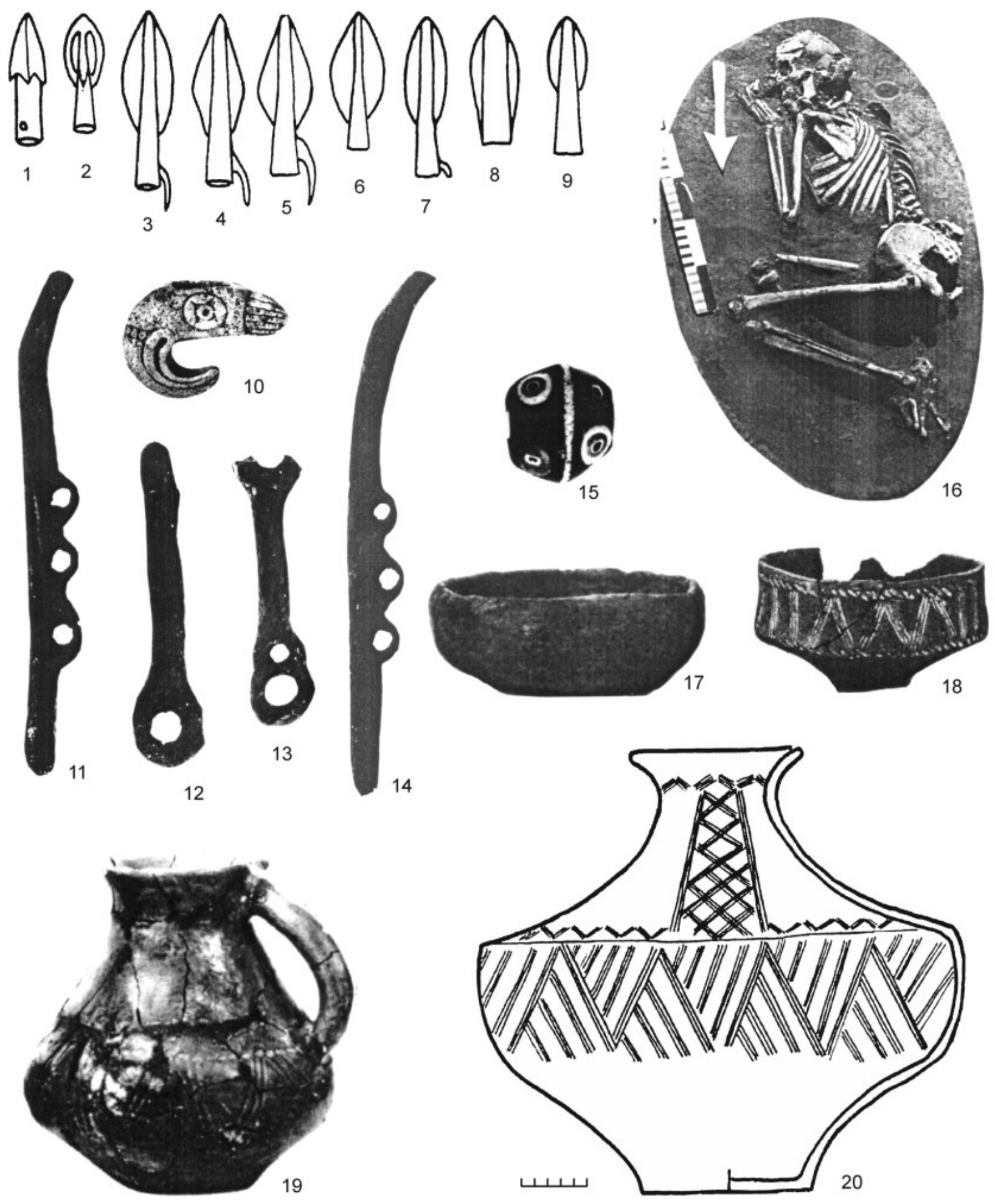
и скифов, ученый пришел к обоснованному выводу, что скифское, достаточно длительное влияние «не привело к нивелировке материальной и духовной культуры аборигенов». Материал «не дает оснований для провозглашения < .. > значительной этнической и культурной ассимиляции кавказцев со стороны степняков» (Там же. С. 180-181). Относительно интенсивности и глубины проникновения кочевых элементов и их влияния на культуру автохтонного населения В. Б. Виноградов справедливо полагал, что это во многом определялось местом расположения центров проживания «кобанцев». В удаленности от степей проникновение и интенсивность в материалах местных могильников просматриваются значительно меньше, чем в материалах памятников, расположенных в контактной зоне предгорий и равнины (Там же. С. 89-90). Данная точка зрения подтвердилась и по материалам памятников, раскопанных позднее. Например, керамика из слоя VI в. до н. э. Хумаринского поселения в верховьях р. Кубани (Абрамова, 1998. С. 5-6; 1999. С. 89-120). Раскопки позволили их автору сделать заключение, что памятник принадлежит к небольшой локальной группе оседлого населения кобанской культуры (Абрамова, 1999. C. 101-102), которая была удалена от контактной зоны и мало подвержена скифскому влиянию (Там же. С. 114-115, рис. 12; 13).

В отличие от находящегося в горах Хумаринского поселения, материалы могильника Султан-Гора 3, расположенного на границе предгорий и равнины, показывают другую картину (Членова, 1984. С. 235 сл.). Здесь на могильнике западного варианта позднекобанской культуры (рис. 4, 1-43) выявлено погребальное сооружение сложной конструкции в виде каменной ограды, внутри которой находились шесть погребений в каменных ящиках (рис. 4, 1) (Там же. С. 236, 240, рис. 1-3). Погребальный инвентарь состоял из оружия скифского типа конца VI - IV в. до н. э. (железные акинаки, топорик, бронзовые и железные стрелы). Одно из погребений сопровождало захоронение коня. По мнению Н. Л. Членовой, могильник был оставлен смешанным каменномостско-скифским (по ее гипотезе) населением и представляет собой одно из свидетельств длительного пребывания скифов на Северном Кавказе. Причем скифский компонент восходит к скифам не Северного Причерноморья, а Северного Кавказа (Там же. С. 239), то есть к потомкам смешанного поколения, последующего за пришедшими сюда степняками.

Подтверждают эту точку зрения и материалы позднекобанского поселения и могильника Уллубаганалы-2 (рис. 5, 1-15). В своем обобщающем труде эти уникальные памятники, находящиеся в пограничной зоне между предгорьями и равниной, В. Б. Ковалевская датирует концом VII - началом VI в. до н. э. (Ковалевская, 2005). Исследователь предложила гипотезу о весьма сложных и многосторонних взаимоотношениях коренного населения со степными пришельцами. Достаточно «сложноструктурированное и сильное в военном отномении» местное сообщество на раннем этапе появления скифских кочевников рассматривалось ею как данность. Предполагалось, что это были взаимоотношения ближайших соседей, при которых «ведущая воинская роль скифов в этих взаимоотношениях была безусловна». Кроме того, они «отражали и союзнические отношения - участие кавказцев в скифских военных походах» (Там же. С. 57). Согласно материалам позднего периода комплекса поселения и могильника Уллубаганалы-2

Рис. 3. Позднекобанский Комаровский могильник конца VII - начала VI в. до н. э.: 1-9 - погребение № 9; 10-14 - погребение № 3; 15 - погребение № 8; 16, 19 - погребение № 5 (типичный погребальный обряд); 17 - погребение № 4; 18 - погребение № 2; 20 - погребение № 6

1-10, 20 -Абрамова, 1974. С. 198, 202, рис. 3, 3, 19, 20; 5; 11-14, 15, 17-19-Козенкова, 1996. С. 29, рис. 11, 6-14;

16 - фото из архива автора

1-9- бронза; 10 - кость; 11-14-железо; 15 - стекло; 17-20 - глина

Fig. 3. Late Koban cemetery of Komarovsky of the late $7^{\text {th }}-$ early $6^{\text {th }}$ century BC: $1-9$ - burial no. 9; $10-14-$ burial no. 3; 15 - burial no. $8 ; 16,19$ - burial no. 5 (typical funerary rite); 17 - burial no. 4; 18 - burial no. 2; 20 - burial no. 6

1-10, 20 -Абрамова, 1974. P. 198, 202, Fig. 3, 3, 19, 20; 5; 11-14, 15, 17-19-Козенкова, 1996. P. 29, Fig. 11, 6-14;

16 - photo from the author's archives

1-9 - bronze; 10 - bone; 11-14 - iron; 15 - glass; 17-20 - clay 

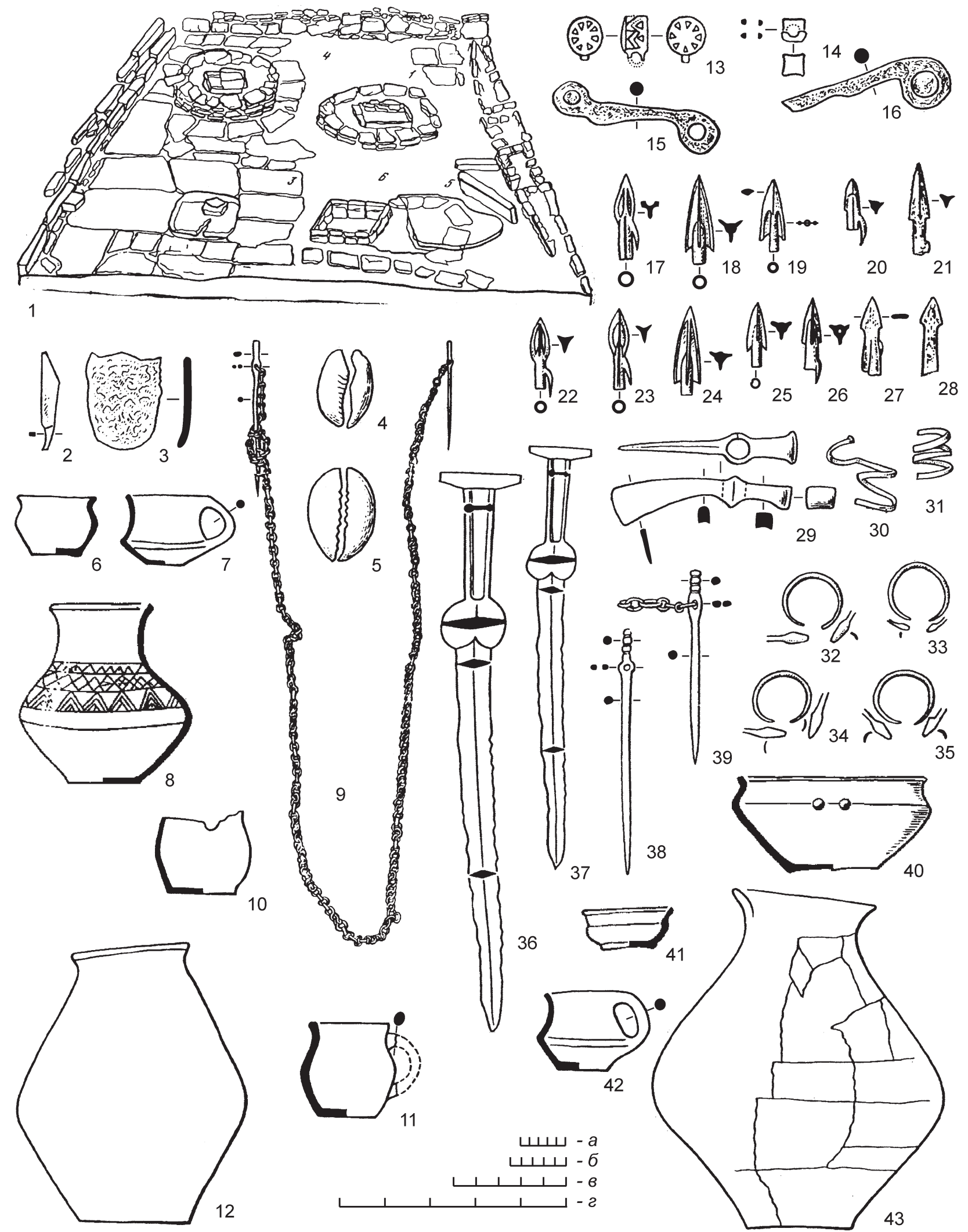
(Ковалевская, 1984. С. 31; Козенкова, 1989. С. 33, табл. XXIII, 7; 89 - сводные табл. по погребальному обряду) В. Б. Ковалевская отметила ряд скифских импульсов в местную позднекобанскую культуру, например, близкие звериному стилю скифов элементы на отдельных предметах. Наиболее показательна роговая рукоятка стального ножа из погребения № 7 (рис. 5, 14), украшенная стилизованными птичьими головками (Козенкова, 1998. С. 12, рис. 2). Интересен факт наличия в одном из каменных ящиков захоронения только отрубленной головы, железного акинака и корчаги как проявления, по мнению В. Б. Ковалевской, скифского обычая, несвойственного обычаям местной культуры (Ковалевская, 2005. С. 63). По материалам могильника прослежен такой важный факт, как антропологическое смешение захороненных. В некоторых мужских черепах преобладали антропологические признаки степного населения. Все это и ряд других доводов, как полагает В. Б. Ковалевская, позволяет говорить о пересмотре «вопроса об удельном весе скифских культурных влияний в позднекобанской культуре в пользу включения собственно скифов в состав тех групп населения, которые были носителями кобано-скифской культуры в равнинном Предкавказье» (Там же. С. 65).

Интересный материал о взаимоотношениях скифов и местного населения получен на территории Ставрополья, где раскопанный у села Прогресс-2 курган находился в ареале западного варианта кобанской культуры - в районе, плотно заселенном «кобанцами», где доминирование степного влияния было особо заметно. Здесь на вершине кургана среднего бронзового века, на небольшой глубине оказалось впускное погребение первой половины VII в. до н. э. (Березин, Маслов, 2016. С. 191, 198). Скелет погребенного подростка лежал под каменной наброской в скорченном положении, на правом боку с завалом на спину, головой на юго-запад. Как особенность погребального обряда авторы публикации отмечают положение ног, согнутых под прямым углом, что, по их мнению, нехарактерно для кобанских могильников. Погребальный инвентарь имел степной облик: четыре бронзовых наконечника стрел (три двухлопастные с удлиненно-ромбическим и один с листовидноасимметричным пером), втулки которых снабжены шипами. Кроме стрел в могиле была, видимо, деревянная чаша, от которой сохранились бронзовые пластины обкладки. С. Я. Березин и В. Е. Маслов отнесли погребение к условно раннескифскому («раннескифское»), полагая, что «из-за отсутствия четких критериев этничности в археологии принадлежность "раннескифских" материалов можно рассматривать гипотетически» (Там же. С. 198). С этим можно было бы согласиться, однако именно особенности погребального обряда являются приоритетными при определении культурной принадлежности могильников. В данном случае скорченная поза, юго-западная ориентировка покойника, перекрытие могилы в виде каменной наброски свидетельствуют о том, что здесь захоронен носитель кобанской культуры. Даже такой способ расположения тела с ногами, согнутыми под прямым углом, объединяет данное погребение с синхронными захоронениями из могильников Мебельная фабрика-1 (погребения № 17, 19, 24, 34, 42), Султангорский-1 (погребение № 7), Клин-Яр II (погребение № 4), Исправная (погребение № 14). Юго-западная ориентировка скелетов имелась в Минераловодском могильнике, в синхронных могильниках Индустрия, Исправная, Уллубаганалы-2 (Козенкова, 1989. Табл. 18; 19), многие погребения которых содержали оружие скифского типа (Виноградов и др., 1980.

Рис. 4. Позднекобанский могильник Султан-Гора 3, VI в. до н. э. Контактная предгорно-степная зона: 1 - погребальное сооружение из камня (реконструкция); 2-9 - погребение $1 ; 10$ - погребение 2; 11-12 - погребение 3; 13 - погребение 4; 14-16 - погребение 5; 17-43 - погребение 6. Масштабы: $a$ - № 6-8, 10-12, 40-43; б - № 9, 29, 32-37; в - № 2, 13-28, 30-31, 38-39; 2 - № 3-5.

1-43 - Членова, 1984. С. 238, 240, рис. 2, 9, 10, 16, 18; 3

2-3, 15-16, 29, 36-37- сталь; 4, 5 - каури; 6, 9, 13-14, 17-28, 30-35, 38-39- бронза; 6-8, 10-12, 40-43-глина

Fig. 4. Late Koban cemetery of Sultan-Gora $3,6^{\text {th }}$ century BC. Contact piedmont-steppe zone: $1-$ stone burial installation (reconstruction); $2-9$ - burial no. $1 ; 10$ - burial no. 2 ; 11-12 - burial no. 3 ; 13 - burial no. 4 ; $14-16$ - burial no. 5; $17-43$ - burial no. 6. Scales: $a-$ no. $6-8,10-12,40-43 ; \sigma-$ no. $9,29,32-37 ; 6-$ no. $2,13-28,30-31,38-39 ; 2-$ no. 3-5. Scales: a - no. $6-8,10-12,40-43 ; 6-$ no. $9,29,32-37 ; 6-$ no. $2,13-28,30-31,38-39 ; 2-$ no. $3-5$

1-43 - Членова, 1984. Р. 238, 240, Fig. 2, 9, 10, 16, 18; 3

$2-3,15-16,29,36-37$ - steel; 4, 5 - cowry; 6, 9, 13-14, 17-28, 30-35, 38-39- bronze; 6-8, 10-12, 40-43-clay 


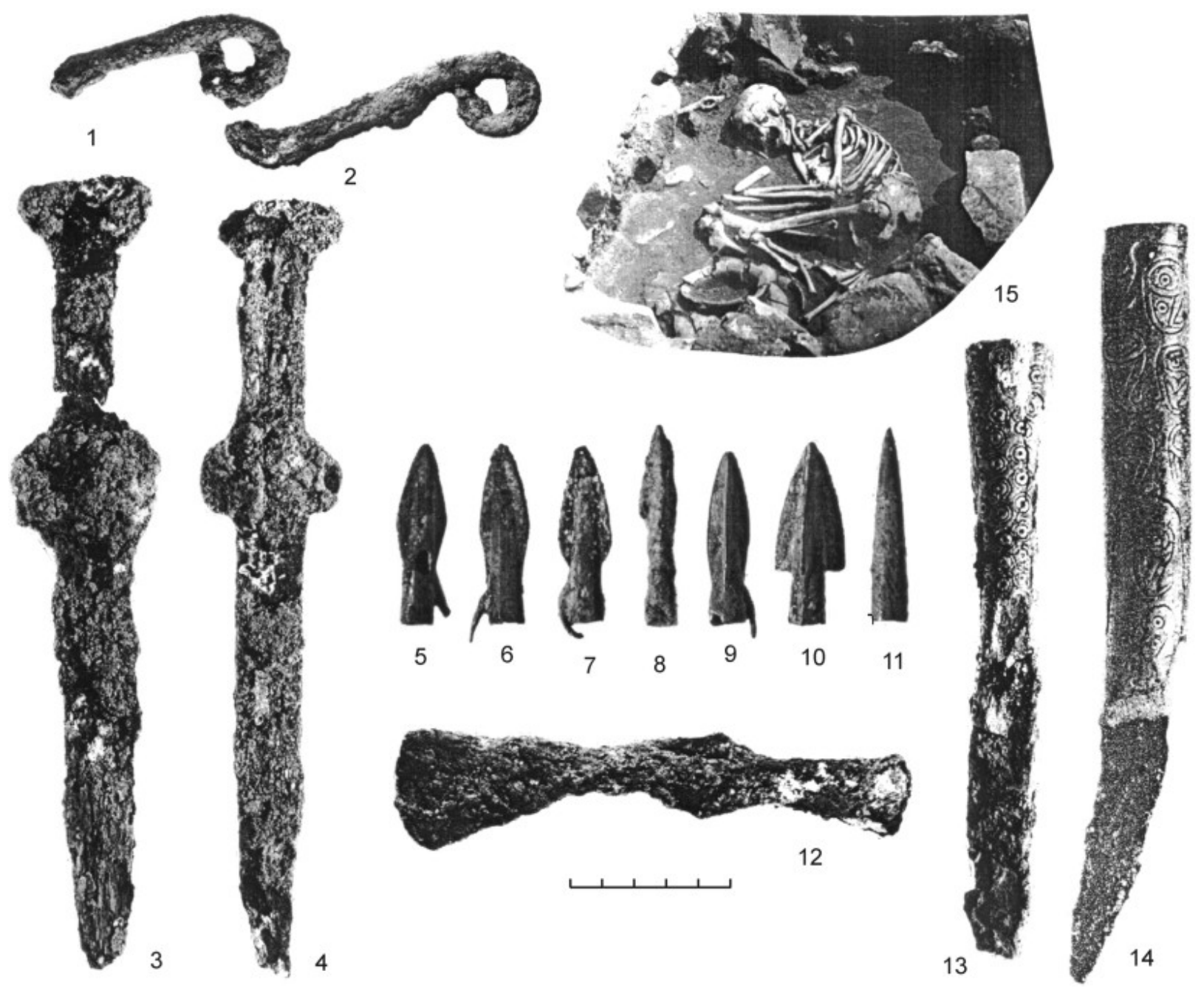

Рис. 5. Предметы скифского типа: 1-6, 9-15 - из могильника Уллубаганалы-2 конца VII-VI в. до н. э.; 7, 8 - из позднекобанского поселения. Контактная предгорно-степная зона.

1, 2, 5, 6, 9, 11 - погребение № 4; 3 - погребение № 5; 4 - погребение № 15; 10 - погребение № 7; 12 - погребение № 2 ; 13 - погребение № 16; 14 - погребение № 7; 15 - погребение № 17, план

1-15 - фото из архива В. И. Козенковой; номера на рисунке частично соответствуют: 3, 4, 10, 12 - Ковалевская, 2005.

С. 246,247 , рис. $11,7,9,12 ; 12$.

1-4, 12 - сталь; 13,14 - сталь и кость; 5-11- бронза

Fig. 5. Objects of Scythian type: 1-6, 9-15- from the cemetery of Ullubaganaly-2 of the late 7th-6th century BC; 7, 8 - from a Late Koban settlement. Contact piedmont-steppe zone.

$1,2,5,6,9,11$ - burial no. $4 ; 3$ - burial no. 5; 4 - burial no. $15 ; 10$ - burial no. $7 ; 12$ - burial no. $2 ; 13$ - burial no. 16 ; 14 - burial no. $7 ; 15$ - burial no. 17 , plan

1-15 - photo from V. I. Kozenkova's archives; numbers in the drawing partly correspond to: 3, 4, 10, 12 - Ковалевская, 2005. P. 246, 247, Fig. 11, 7, 9, 12; 12.

1-4, 12 - steel; 13, 14 - steel and bone; 5-11- bronze

С. 189 , рис. 3 , 1; 4, 1; Дударев, Рунич, 1992. С. 4, 7 , рис. 2,$1 ; 5,1 ;$ Козенкова, 1989. Табл. XXVI, 1 ; XXVII, 6; XXXV, 2, 6; Рунич, 1971). В скорченной позе, с ногами, согнутыми под прямым углом, захоронен покойник и в погребении № 13 могильника Уллуба- ганалы-2. Отличает впускное погребение из кургана Прогресс-2 от вышеуказанных аналогий лишь большой удельный вес скифского влияния в погребальном инвентаре. В данном случае уместно констатировать смешанность обряда. 
Проведенный обзор показал, что по основным выделенным мной аспектам мнения скифологов и кавказоведов, специально занимающихся кобанской культурой, во многом совпадают. Можно считать общепризнанным, что главной причиной трансформации кобанской культуры на позднем этапе ее развития является вооруженное вторжение на территорию коренного оседлого населения отрядов кочевых скифов, проживавших по соседству в степных районах. Очевидно и саморазвитие местной культуры как вполне самодостаточного социального общества. Очевидна и большая роль внедрения различных новаций как в производственную сферу (качественно новые формы железного оружия, новые типы конского снаряжения), так и в повседневную культуру. В последнем случае речь идет о новой моде в костюме, отдельные элементы которого (бронзовые пряжки с кругами) могут выступать не только хронологическими индикаторами для ряда памятников по обе стороны склонов Кавказа, но также указывать на этническое родство оставившего их населения (Козенкова, 2007. С. 258-279; Рамишвили и др., 1987. С. 83, табл. CXLIII, 1, 2).

Во многом близки взгляды специалистов и по проблеме степени и интенсивности трансформации культуры автохтонного населения. Однако вслед за Е. И. Крупновым и В. Б. Виноградовым многие исследователи (С. Л. Дударев, С. В. Махортых и другие, в том числе автор) разделяют мнение о том, что степное влияние хотя и показывает изменения кобанской культуры на позднем ее этапе, но не нарушило местный субстрат.

Относительно политического аспекта взаимоотношений скифов и населения, носителей позднекобанской культуры, взгляды специалистов, напротив, выглядят неоднозначными и подчас противоречивыми. Например, общим местом стало утверждение о почти тотальном политическом господстве скифов в ареале кобанской культуры в течение всего позднего этапа. Так, В. А. Ильинская и А. И. Тереножкин считали, что скифы являлись главной политической силой на территории кобанских племен. Отмечая следы культуры кочевников в материальной культуре аборигенов, исследователи указывали на наличие «местного населения, сохранившего оседлый образ жизни и не вовлеченного в круговорот скифских событий» (Ильинская, Тереножкин, 1983. С. 25) (курсив мой. - В. К.). По В. Б. Виноградову, в начале VII - VI в. до н. э. «диктовать свою волю и власть» местному населению, при помощи вооруженной силы держать его в «покорности и зависимости», совершать «сокрушительные погромы» был основной способ подчинения. Одновременно он видел в «кобанцах» «союзников и соучастников походов» в Переднюю Азию (Виноградов, 1972. С. 42, 75-78, 86) (курсив мой. - В. К.). Такая же нелогичность, исходя из контекста, отмечается и у С. Л. Дударева. С одной стороны, «последствия его (населения. - В. К.) первого столкновения с пришлыми скифами были самыми отрииательными», даже в позднее пребывание «отдельные группы скифов задержались в равнинно-степном Предкавказье < ..> по-прежнему господствуя над <...> группами северокавказцев». А с другой стороны, уже к началу VI в. до н. э. возникла необходимость «новых пополнений $<\ldots>$ на переднеазиатском театре $<\ldots>$ военной силы, которой могли стать соседние северокавказские племена» (Дударев, 1991. С. 43, 45, 49) (курсив мой. - В. К.). Политическое господство над местным населением, по мнению С. В. Махортых, было основой социально-политической структуры скифов. Причем активный период военных грабежей, «насильственное отчуждение произведенного продукта» у оседлого населения кобанской культуры, грабительские набеги для сбора дани охватывают весь VII в. до н. э. Далеко не мирные отношения с трагическими последствиями продолжаются и в VI в. С другой стороны, согласно исследователю, можно сделать заключение о «глубоких, длительных и постоянных связях двух различных этносоциальных образований VII-V вв. до н. э.» (Maxортыхx, 1991. C. 101, 105). По мнению М. П. Абрамовой, скифы, обладая яркой, выразительной культурой, оказали сильное влияние на культуру местного населения. Однако их политическое господство было неравнозначное в разных частях ареала позднекобанской культуры. Лишь «на территории Ставрополья и Кабарды скифская культура имеет стойкие признаки, в особенности погребальный обряд» (Абрамова, 1992. С. 22-23). По мнению В. Е. Маслова, политическому доминированию скифов в этих регионах вплоть до IV в. до н. э. (Новозаведенное) способствовал и природный ландшафт, благоприятный для хозяйственной деятельности (Маслов, 2016. С. 165-167). 
Представления В. А. Ильинской и А. И. Тереножкина, что «скифская дорога была прорублена при насильственном подавлении всяких попыток воспрепятствовать продвижению скифов» (Ильинская, Тереножкин, 1983. С. 22) (курсив мой. - В. К.), не подтверждают материалы высокогорных могильников Центрального Кавказа, как Тлийский, Верхне-Кобанский, Кливанский, Гастон Уота. Состав погребального инвентаря наиболее информативного Тлийского могильника (206 могил скифского периода) показывает, что традиционная культура претерпела изменения больше за счет саморазвития (Техов, 1985; 2002). Особенно это прослеживается на атрибутах костюма, украшениях, сакральных предметах. Хотя формы бронзовых браслетов стали лаконичнее, все же дуговидные фибулы, бронзовые пояса, прямоугольные пряжки, ножные браслеты по-прежнему составляли аксессуары мало изменившегося костюма. Сохранились также традиционные бронзовые кружки с зооморфными ручками и миски.

Важную роль в трансформации бытовой культуры сыграло широкое освоение железоделательного ремесла. Появились железные браслеты, фибулы и гривны. Особенно это сказалось на вооружении. Топоры, кинжалы традиционных и общекавказских типов, однолезвийные кинжалы с грибовидным навершием, большие ножи и секиры теперь изготавливались из железа. Тем не менее в арсенале по-прежнему сохранились зачастую традиционные бронзовые орнаментированные прямообушные и клиновидные (так называемые колхидские) топоры. Отмечены изменения в типах бронзовой посуды. Для инвентаря стали типичными бронзовые ведерки (Техов, 2002. Табл. 100, 3; 102, $8)$, иногда с железными дужками. Можно согласиться с Б. В. Теховым, что некоторая трансформация также была «обусловлена общим ростом культурных и хозяйственных связей с племенами соседних народов и областей, в первую очередь с племенами Закавказья и Передней Азии» (Техов, 1980. С. 257). Яркое свидетельство тому - бронзовые орнаментированные пояса, три из которых (погребения № $363,419,425)$ были урартскими по происхождению (Техов, 2002. С. 22, 42, 45).

Относительно степени и интенсивности влияния культуры скифов на местную культуру высоко- горного могильника, то из 206 изобилующих оружием тлийских могил только в 13 найдены один биметаллический (Техов, 1980. Рис. 85, 7) и 12 железных скифских акинаков, или чуть более 5 \% (Техов, 1980; 2002). В комплекте с акинаком (погребение № 129) найден один бронзовый втульчатый наконечник стрелы с удлиненно-ромбическим пером с шипом (Техов, 1980. Рис. 11, 32). Кроме того, имелось около десятка роговых деталей, выполненных в скифском зверином стиле от несохранившихся предметов, один наконечник в виде головки хищной птицы (грифон) из погребения № 246 украшал, видимо, деревянные ножны железного кинжала кавказского типа (Там же. Рис. 18, 2).

В. А. Ильинская и А. И. Тереножкин считали тлийские материалы скифского типа наиболее ранними и датировали их не VII-VI вв. до н. э., а только VII в. до н. э. (Ильинская, Тереножкин, 1983. С. 32). По моему мнению, ничтожное количество кочевнических находок, среди которых преобладают самые ранние, свидетельствует скорее о стремительном проходе скифов через перевалы высокогорья мимо хорошо защищенных поселений коренных жителей, оставив только немногочисленные следы военных стычек. Впрочем, Б. В. Техов предположил, что какие-то небольшие группы скифов «могли остаться в горных районах Центрального Кавказа, в том числе и на южном склоне» (Техов, 2002. С. 257). Могилы VI-V вв. до н. э., составляющие около четверти от общего числа, свидетельствуют о стабильном состоянии местной культуры, во многом с унифицированным бытовым погребальным инвентарем (поясные пряжки, типы браслетов и гривен, серьги, ожерелья из традиционных сердоликовых бус). Типы железного оружия тяготели не только к металлургическим центрам Северного Кавказа, но и Закавказья. Позднескифское влияние, но не доминирующее господство кочевников, сказалось в малочисленных (от одного до шести) наборах бронзовых наконечников конца $\mathrm{V}$ - начала IV в. до н. э., эпизодически встречающихся роговых украшениях ножен кинжалов и в особенностях изображений в зверином стиле на бронзовых поясах.

В этой связи показателен погребальный инвентарь части мужских могил Кливанского могильника в высокогорном ущелье р. Меджуда (левобережье 
p. Большая Лиахва). Наряду с железными однолезвийными кинжалами с грибовидным навершием, как в Тли, здесь обнаружены особого варианта железные топоры и мотыга, неизвестные на северном склоне. В то же время почти каждое погребение содержало единичные бронзовые наконечники стрел, известен поздний вариант бронзового наконечника ножен в виде головы грифона. Среди украшений стеклянные привески каплевидной формы, как в Луговом, и поясные пряжки с кругами, как в Тлийском, Верхне-Кобанском, Архонском и Луговом могильниках (Козенкова, 2007. С. 267, рис. 7-12). Среди украшений Кливанского могильника важна находка серьги кольцевидной формы с припаянными тремя столбиками из зерни. Подобный тип серег не обычен для позднекобанской культуры, но типичен для V-IV вв. до н. э. в культурах Закавказья, что может служить доказательством продолжения экономических связей между «кобанцами» и племенами Закавказского региона.

Близкий по составу погребального инвентаря (оружие, керамика, пряжка с кругами и т. п.) могильник открыт на территории Грузии близ сел. Аргуни, северо-западнее Душети. Этот географический район находится «на стыке Картлийского и Алевского хребтов, где с древнейших времен проходили кратчайшие дороги, связывающие Ксанское и Арагвское ущелья с Северным Кавказом» (Рамишвили и др., 1987. С. 83, табл. CXLIII, $1,2)$. Кроме того, именно в Ксанском ущелье был найден известный бронзовый пояс V в. до н. э. с ажурной пряжкой с кругами, украшенный изображениями оленей (Доманский, 1984. Ил. 51). Стиль изображения оленей, по моему мнению, представляет собой образец творческой переработки кобанскими мастерами элементов скифского звериного стиля с возвратом к исконно местным изобразительным приемам, на что указывают положение ног, форма рогов, циркульный орнамент в сочетании с ломаной линией (Козенкова, 2007. С. 269-270, рис. 13, 1, 2). Следующий более поздний этап возврата к исконным изобразительным традициям, возможно, в конце V - начале IV в. до н. э., виден в стилизованных изображениях оленя и быка на фрагменте бронзового пояса из погребения № 64/128 Лугового могильника. Рисунки животных сочетаются с гравированной ломаной линией на конце пояса, который по контуру дополнен гравированным пояском с косыми насечками (Мунчаев, 1963. С. 184-187, рис. 29, 11; Козенкова, 1982. С. 51-52, табл. XXIX, 2).

Древности Дигорского ущелья позднекобанского времени наиболее достоверно представлены стационарно раскопанным высокогорным могильником Гастон Уота (Мошинский, 2006). Материалы памятника свидетельствуют, что причина трансформации культуры VII-IV вв. до н. э. в этом районе Северного Кавказа обусловлена, как и в других частях ареала кобанской культуры, скифскими походами в Переднюю Азию. Однако здесь, в стороне от основных маршрутов, степень и интенсивность скифского влияния была значительно меньше, чем в предгорно-равнинной полосе Северного Кавказа. В силу некоторой замкнутости географического положения Дигории многие черты бытовой культуры имели свою специфику: особый тип железного дротика, бронзовые поясные пряжки дигорского типа, некоторые типы браслетов и др. Что касается характера кобано-скифских взаимоотношений и хронологии, то на основе анализа погребального инвентаря А. П. Мошинский выделяет четыре этапа: 1) VII-VI вв. до н. э.; 2) вторая половина VI в. до н. э.; 3) конец VI - середина V в. до н. э.; 4) конец V - начало IV в. до н. э. (Там же. С. 87). В целом, можно согласиться с предложенной исследователем динамикой событий, базирующейся на материалах могильника Гастон Уота и всего массива позднекобанских древностей Дигорского ущелья. На раннем этапе, в VII - начале VI в. до н. э., в общекобанских типах и категориях вещей еще ощущается отзвук скифских походов через Кавказ. Особо заметна общая вооруженность местного населения, но в то же время наблюдается слабая трансформация местного погребального обряда, известны конские захоронения, бляшки конского убора в скифском зверином стиле, бронзовые наконечники стрел скифского типа как проявление степного влияния (Там же. С. 23-24). Со второй половины VI в. до н. э. наступает период стабилизации. В конце $\mathrm{V}$ - начале IV в. до н. э. возникает качественно новая форма контактов со степным миром, предполагающая своеобразный консенсус, выразившийся «во взаимопроникновении элементов двух столь разных по облику культур». По мнению А. П. Мошинского, 
для этого времени вообще не следует преувеличивать степное влияние в регионе (Там же. С. 88-89), поскольку оно не привело к активному процессу иранизации коренного населения гор. Особенность позднекобанских древностей Дигории - это заметное в V-IV вв. до н. э. влияние культур Закавказья, особенно горной Рачи и колхского царства (кольцевидные серьги с двумя или тремя столбиками зерни, протома изображения двух лошадей - элемент золотой подвески, типы бронзовых священных жезлов). В среде горцев Дигории наметилась социальная дифференциация (рост всадничества, жреческая верхушка). Долгое время культура Дигории оставалась традиционно кобанской, но с заметными элементами консерватизма.

Обращаясь к вопросам хронологии кобано-скифских взаимоотношений, можно отметить близкие мнения среди специалистов, скифологов и кавказоведов. Эти отношения развивались около 300 лет - от захватнических военных конфликтов в начале контактов (середина VII в. до н. э.) до фактически полной стабилизации в конце $\mathrm{V}$ - начале IV в. до н. э. Разногласия имеются только в определении длительности военной стадии. Большинство специалистов определяет ее в более чем полвека (середина VII - начало VI в. до н. э.). Для горных районов В. А. Ильинская и А. И. Тереножкин отводили ей только VII в. до н. э. По моему мнению, активные военные акции между скифами и хорошо вооруженным воинским контингентом «кобанцев», судя по обилию в местных могилах разнообразного оружия, могли продолжаться менее одного поколения. Об этом свидетельствует, например, стратиграфия на Сержень-юртовском поселении. Между остатками ранних помещений XI - начала VII в. до н. э. и поздних строений середины VII-V в. до н. э. отсутствует хиатус. В частности, помещение № 14 VI в. до н. э. расположено на мостовой № 1 из гальки раннего периода (Козенкова, 2001. С. 84-85, табл. 5; рис. 27). При такой ситуации снимается вопрос, связанный с гипотезой об участии местных кобанских воинов в переднеазиатских походах. Видимо, уже к концу VII - началу VI в. до н. э. между элитами скифов и носителей позднекобанской культуры возник консенсус, устное соглашение о разделении политической власти в регионе и на этой договорной основе - приглашение местных вооруженных отрядов для продолжения дальних походов. Кроме привлекаемых ранее данных, среди которых наиболее значима находка в скифском кургане № 1 Краснознаменского могильника бронзовой обкладки дышла с изображением богини Иштар (Петренко, 2006. С. 106-107, табл. 51, 66), свидетельством очевидного вовлечения автохтонного населения в военные скифо-кобанские экспедиции на рубеже VII-VI вв. до н. э. служит ранее недооцененная находка в кенотафе из Перкальского позднекобанского могильника бронзового клевца («чекана»), представляющего, видимо, импорт из Малой Азии. Типологически, морфологически, возможно, хронологически это изделие совпадает с клевцом из погребения № 9 могильника Имерлир - самым древним (700-650 гг. до н. э.) из малоазийских памятников (Козенкова, 2013. С. 104, 106, рис. 54, 8). Перкальский кенотаф, возможно, был сооружен вернувшимися из похода домой сородичами в память о погибшем на чужбине воине-«кобанце».

Таким образом, наиболее противоречивым, на мой взгляд, является вопрос сосуществования двух разных этнокультурных сообществ. С одной стороны, почти всеми специалистами принимается постулат политической власти скифов над населением обширного региона. С другой - имелась устоявшаяся многовековая культура, общество воинственных, избыточно вооруженных горцев с регламентированным бытом. Якобы имевшее место тотальное подчинение власти кочевников после внезапного разрушительного нападения, скорее всего, не могло не вызвать вооруженный отпор. Противоречащее всему - одновременное приглашение принять участие в совместных переднеазиатских походах. Выдвигаемые некоторыми специалистами постулаты о грабежах и данничестве на протяжении всего периода обитания скифов в Предкавказье. И наконец, достоверно отмечаемые по материалам поселений и могильников самостоятельные связи и даже мигращии «кобанцев» далеко за пределы ареала, главным образом в Закавказье, а также в Причерноморье, в Подунавье и Поволжье (Мошинский, 2006; Козенкова, 2013).

Все сказанное позволяет думать, что практически сразу после активного военного этапа отношения могли строиться на основе принципа «вооруженного уважения» (Виноградов, 1972). Безусловно, 
сохранялись культурные взаимовлияния при доминировании скифских элементов, в особенности в степном Предкавказье. Для этой части ареала можно говорить о политической власти скифов в полной мере (взыскание дани, захват скота, карательные акции, процесс смешения населения т. п.). В целом, на территории обитания кобанских племен, как справедливо полагали В. А. Ильинская и А. И. Тереножкин, «после первых столкновений <..>> сложились определенные отношения, гарантирующие беспрепятственное передвижение скифов через Кавказ в страны Передней Азии, тем более, что археологические памятники не воссоздают картину повсеместного уничтожения и разгрома на путях скифского продвижения» (Ильинская, Тереножкин, 1983. С. 25) (курсив мой. - В. К.).

Возникает вопрос: какова же эта формула власти, наиболее адекватная кобано-скифским отношениям того периода? Более 20 лет назад мною была предложена такая модель (Козенкова, 1996. С. 144; 2008. C. 74, 76), которая, кроме полного отрицания (Маслов, 2016. С. 167), не вызвала интереса исследователей, хотя она объясняет столь долгую «живучесть», по выражению Е. И. Крупнова, традиционной автохтонной культуры. Это модель вооруженного нейтралитета. Подобное понятие отражало взаимоотношения между двумя долговременно соседствовавшими, различными по культуре сообществами, основанные на устной договоренности: - отказ от постоянных военных акций, но с сохранением оборонительного вооруженного потенциала; - соблюдение разграничительной линии соприкосновения в условиях горного региона; - невмешательство в бытовой уклад соседей; - обоюдный обмен продукцией жизнеобеспечения, в том числе условиями использования зимних пастбищ в степной зоне - эпицентре обитания кочевников.

О реальности существования такой модели взаимоотношений, включающих непременную устную договоренность между двумя контактирующими сообществами, вооруженным оседлым населением и скифами, в близком по экологии регионе доносит Лукиан (II в. н. э.) в диалоге «Токсарид, или О дружбе» (гл. 44-55), приводя свидетельство Токсарида, присутствовавшего по поручению Солона в V в. до н. э. на Боспоре. Ток- сарид сообщал рассказ посланца скифов, обитавших в ближайших окрестностях. Вожди кочевников поручили передать боспорцам ответ на их жалобу о якобы незаконных набегах скифов на их владения, в частности, на места пастбищ. «Скифы считают, передал посланец, - что ни в данное время, ни впредь ваши пастухи не должны переходить на равнину, но пусть пасут стада до границы каменистой почвы. Грабители же, на которых вы жалуетесь, что они делают набеги на вашу землю, посылаются не по общему решению, но каждый грабит на свой страх. Если кто-то из них будет захвачен, то ты вправе его наказать. Вот что скифы поручили мне передать» (цит. по: Сапрыкин, 2012. С. 185-209) (курсив мой. - B. К.).

Близкие баланс сил и условия сохранения относительного социального спокойствия, необходимого для сосуществования в заданных условиях, могли иметь место в рассматриваемом регионе.

Несколько иначе, видимо, развивались события в области постоянного обитания скифов в окружении населения кобанской культуры: поборы, дань, захват скота, - что не обходилось без сопротивления, а значит, и без карательных акций. В этой связи важны материалы могильника Пелагиада на Ставрополье (Петренко, 1984. С. 155 сл.; Козенкова, 1989. С. 55-56, рис. 6). Среди типичных по обряду кобанских погребений (в одном из них находился покойник, убитый наконечником стрелы, датирующимся VI в. до н. э.) выделяется могила с коллективным захоронением взрослых и детей, со следами насильственного умерщвления и признаками огневого ритуала. По мнению многих специалистов, именно в этой части ареала кобанской культуры особо активно шел процесс смешения разноэтничного населения (Козенкова, 2008. С. 76-77). Можно согласиться с С. Б. Бурковым и В. Е. Масловым, «что территория Предкавказья к V в. до н. э. превратилась в периферийную провинцию скифской культуры. Важнейшими особенностями этого региона было наличие значительных групп автохтонного населения и близость к Закавказью» (Бурков, Маслов, 2007. С. 309) (курсив мой. - B. К.). Последнее заключение особенно важно. О том, что скифы пришли на земли, уже заселенные носителями кобанской культуры, свидетельствуют слои доскифского периода на 
Грушевском (Козенкова, 1989. С. 165, табл. XVIII) и Татарском городищах близ г. Ставрополя. Особенно показательны раскопки Татарского городища, где прослежены участки раннего слоя, которые «свидетельствуют о стабильном проживании на < .. > территории городища "кобанцев"» (Березин и др., 2012. С. 43, рис. 66). В связи с этим предположение, что «кобанцы были переселены скифами...» (Ковалевская, 2005. С. 65) на Ставропольскую возвышенность, остается только одной из версий.

Абрамова, 1974 - Абрамова М. П. Погребения скифского времени Центрального Предкавказья // СА. 1974. № 2.

Абрамова, 1992 - Абрамова М. П. Некоторые особенности взаимоотношений ираноязычных кочевников и оседлых племен // РА. 1992. № 2.

Абрамова, 1998 - Абрамова М. П. Некоторые особенности поселений скифского времени Верхней Кубани // ХХ Крупновские чтения по археологии Северного Кавказа. Железноводск, 1998.

Абрамова, 1999 - Абрамова М. П. Поселение скифского времени у аула Хумара на Верхней Кубани // Древности Северного Кавказа. М., 1999.

Багаев, 2008 - Багаев М. Х. Культура горной Чечни и Дагестана. М., 2008.

Березин и др., 2012 - Березин Я. Б., Каминский В. Н., Малашев В. Ю. Татарское городище и формирование памятников типа Татарка-Вербовка. М., 2012.

Березин, Маслов, 2016 - Березин С. Я., Маслов В. Е. «Раннескифское» погребение в могильнике Прогресс-2 // КСИА. 2016. Вып. 245, ч. I.

Бурков, Маслов, 2007 - Бурков С. Б., Маслов В. Е. Воинские погребения из курганов у станицы Ассиновской // Северный Кавказ и мир кочевников в раннем железном веке. М., 2007 (МИАР; Т. 8).

Виноградов, 1972 - Виноградов В. Б. Центральный и Северо-Восточный Кавказ в скифское время. Грозный, 1972.

Виноградов и др., 1980 - Виноградов В. Б., Дударев С. Л., Рунич А. П. Киммерийско-скифские связи // Скифия и Кавказ. Киев, 1980.

Доманский, 1984 - Доманский Я. В. Древняя художественная бронза Кавказа в собрании Государственного Эрмитажа. M., 1984.

Дударев, 1991 - Дударев С. Л. Очерки древней культуры Чечено-Ингушетии. Грозный, 1997.

Дударев, Рунич, 1992 - Дударев С. Л., Рунич А. П. К вопросу о степном влиянии на вооружение и войско северокавказцев в VII-V вв. до н. э. (на примере Пятигорья). Грозный, 1992.

Иессен, 1941 - Иессен А. А. Археологические памятники Кабардино-Балкарии // Материалы по археологии КабардиноБалкарии. М.; Л., 1941 (МИА; № 3).

Ильинская, Тереножкин, 1983 - Ильинская В. А., Тереножкин А. И. Скифия VII-IV вв. до н. э. Киев, 1983.

Ковалевская, 1984 - Ковалевская В. Б. Кавказ и аланы. Века и народы. М., 1984.

Ковалевская, 2005 - Ковалевская В. Б. Кавказ - скифы, аланы I тыс. до н. э. - I тыс. н. э. М., 2005.

Козенкова, 1982 - Козенкова В. И. Типология и хронологическая классификация предметов кобанской культуры. Восточный вариант. М., 1982 (САИ; Вып. В 2-5, Т. 2).

Козенкова, 1989 - Козенкова В. И. Кобанская культура. Западный вариант. М., 1989 (САИ; Вып. В 2-5, Т. 3).

Козенкова, 1995 - Козенкова В. И. Оружие, воинское и конское снаряжение племен кобанской культуры (систематизация и хронология). Западный вариант. М., 1995 (САИ; Вып. В 2-5, Вып. 4).

Козенкова, 1996 - Козенкова В. И. Культурно-исторические процессы на Северном Кавказе в эпоху поздней бронзы и в раннем железном веке (Узловые проблемы происхождения и развития кобанской культуры). М., 1996.

Козенкова, 1998 - Козенкова В. И. Материальная основа быта кобанских племен. Западный вариант. М., 1998 (САИ; Вып. В 2-5, Т. 5).

Козенкова, 2001 - Козенкова В. И. Поселок-убежище кобанской культуры у аула Сержень-юрт в Чечне как исторический источник (Северный Кавказ). М., 2001.

Козенкова, 2002 - Козенкова В. И. У истоков горского менталитета. Могильник эпохи бронзы - раннего железа у аула Сержень-юрт, Чечня // Материалы по изучению историко-культурного наследия Северного Кавказа. М., 2002. Вып. III. 
Козенкова, 2007 - Козенкова В. И. Специфика некоторых атрибутов костюма древних «кобанцев» как показатель процесса миграции // Северный Кавказ и мир кочевников в раннем железном веке. М., 2007 (МИАР; Т. 8).

Козенкова, 2008 - Козенкова В. И. О процессах пространственной подвижности границ ареала кобанской культуры // Проблемы современной археологии. М., 2008 (МИАР; Т. 10).

Козенкова, 2013 - Козенкова В. И. Кобанская культура и окружающий мир. М., 2013.

Козенкова, Найденко, 1980 - Козенкова В. И., Найденко А. В. Кобанский могильник близ станицы Исправной (Ставрополский край) // СА. 1980. № 1.

Кореняко, 1990 - Кореняко В. А. О времени появления раннескифских памятников на Северном Кавказе // Дон и Северный Кавказ в древности и средние века. Ростов н/Д, 1990.

Крупнов, 1941 - Крупнов Е. И. Археологические памятники Ассинского ущелья // Работы археологических экспедиций. М., 1941 (Тр. ГИМ; Вып. ХІІ).

Крупнов, 1948 - Крупнов Е. И. Археологические памятники верховьев р. Терек и бассейна р. Сунжа // Археологический сборник. М., 1948 (Тр. ГИМ; Вып. XVII).

Крупнов, 1949 - Крупнов Е. И. К вопросу о поселениях скифского времени на Северном Кавказе // КСИИМК. 1949. T. XXIV.

Крупнов, 1955 - Крупнов Е. И. О состоянии и задачах изучения археологии Кавказа // КСИИМК. 1955. Т. 60.

Крупнов, 1960 - Крупнов Е. И. Древняя история Северного Кавказа. М., 1960.

Кузнецова, 1992 - Кузнецова Т. М. Памятники бассейна Кубани в контексте скифской архаики // XVII Крупновские чтения по археологии Северного Кавказа: Тез. докл. Майкоп, 1992.

Кузнецова, 2015 - Кузнецьова Т. М. Хронология Келермесского могильника и скифские заимствования // АСГЭ. 2015. Вып. 40 .

Лесков, 1965 - Лесков А. М. Горный Крым в первом тысячелетии до н. э. Киев, 1965.

Маслов, 2016 - Маслов В. Е. Раннескифская история и Геродот // Кавказ и степь на рубеже эпохи поздней бронзы и раннего железа: Материалы междунар. науч. конф., посвящ. памяти М. Н. Погребовой. М., 2016.

Maxopmblx, 1991 - Maxopmblx C. В. Скифы на Северном Кавказе. Киев, 1991.

Мошинский, 2006 - Мошинский А. П. Древности горной Дигории VII-IV вв. до н. э. Систематизация и хронология. М., 2006 (Тр. ГИМ; Вып. 154).

Мунчаев, 1963 - Мунчаев Р. М. Луговой могильник (исследования 1956-1957 гг.) // Древности Чечено-Ингушетии. М., 1963.

Петренко, 1984 - Петренко В. Г. Погребальные комплексы и находки у сел. Пелагиада // СА. 1984. № 2.

Петренко, 2006 - Петренко В. Г. Краснознаменский могильник. Элитные курганы раннескифской эпохи на Северном Кавказе. М.; Берлин; Бордо, 2006.

Петренко и др., 2000 - Петренко В. Г., Маслов В. Е., Канторович А. Р. Хронология центральной группы курганов могильника Новозаведенное-ІІ // Скифы и сарматы в VII-III вв. до н. э.: палеоэкология, антропология и археология. М., 2000.

Петренко и др., 2006 - Петренко В. Г., Маслов В. Е., Канторович А. Р. Погребения подростков в могильнике Новозаведенное-ІІ // Древности скифской эпохи. М., 2006.

Петренко, Маслов, 1996 - Петренко В. Г., Маслов В. Е. Исследование Новозаведенского-ІІ могильника // Актуальные проблемы археологии Северного Кавказа. ХІХ Крупновские чтения по археологии Северного Кавказа. М., 1996.

Пиотровский, Иессен, 1940 - Пиотровский Б. Б., Иессен А. А. Моздокский могильник // Археологические экспедиции Эрмитажа. Л., 1940. Вып. 1.

Рамишвили и др., 1987 - Рамишвили Р. В., Джорбенадзе В. А., Чиковани М. Е., Глонти М. Г. и др. Археологическое изучение Арагвского ущелья // Полевые археологические исследования в 1985-1986 годах (краткие сообщения). Тбилиси, 1987.

Рунич, 1971 - Рунич А. П. Отчет о полевых исследованиях в районе Кавминвод в 1971 году // Архив ИА АН СССР. Ф-1. № 4633.

Сапрыкин, 2012 - Сапрыкин С. Ю. Боспорские сюжеты в диалоге Лукиана «Токсарид» // Аристей: классическая филология и античная история. М., 2012. Т. 5. 
Смирнов, 1964 - Смирнов К. Ф. Савроматы. М., 1964.

Техов, 1980 - Техов Б. В. Скифы и материальная культура Центрального Кавказа в VII-VI вв. до н. э. // Скифия и Кавказ. Киев, 1980.

Техов, 1985 - Техов Б. В. Тлийский могильник: Каталог. Тбилиси, 1985. Т. III.

Техов, 2002 - Техов Б. В. Тайны древних погребений. Владикавказ, 2002.

Членова, 1984 - Членова Н. Л. Могильник VI в. до н. э. Султан-Гора III под Кисловодском // Древности Евразии в скифо-сарматское время. М., 1984.

\section{Essay on some aspects and the vector of development of Koban-Scythian interrelations}

\section{I. Kozenkova}

This paper is connected with the $80^{\text {th }}$ anniversary of Evgeniy I. Krupnov's excavations of sites of the Koban culture (Alkhaste, Nesterovskaya settlementsite, Nesterovskoye burial ground) in the Assa River Gorge in Ingushetia in the Northern Caucasus. Here the question is once again raised about the interrelations between the autochthonous culture and the steppe culture of the Scythians proper of which elements were distinguished at the abovementioned sites (1941, 1948). Archaeological sources accumulated during this period concerning the late Koban culture enable us to review some important aspects and the vector of development of the two cultures of different ethos's in the $7^{\text {th }}-4^{\text {th }}$ century BC. It is generally accepted among students of the Caucasus and scythologists to distinguish mainly four problems here as the most important ones, viz. the causes of the transformation of the Koban culture at its later stage; the extent and depth of this transformation; the form and model of the interrelations as are deduced from different sources (archaeology, anthropology, ethnography etc.) and the chronological aspect. In the monograph by E. I. Krupnov 'Drevnyaya istoriya Severnogo Kavkaza' (Ancient history of the Northern Caucasus) published in 1960, the historiography of these aspects was thoroughly analysed and a fairly convincing conception of the subject under consideration was proposed. However the evidence accumulated and studied by different authors throughout half a century, in particular a series of Scythian kurgans in the Ciscaucasia, have engendered significant corrections although treating the abovementioned scientific directions differently in different works. The author of the present article, on the basis of the most vivid examples of local sites situated at different mountainous altitudes, notes the relative unity of the views concerning three of the mentioned aspects and contradictions in the interpretation of the form of the interrelations. In particular, the author proposes a model most adequate, in her opinion, to the available data on the interrelations between the 'Kobans' and Scythians for a period of 300 years. This is a model of an armed neutrality according to a verbal treaty between the upper strata of the two equally armed contacting unities. This agreement included the cease of continuous military activities but with the preservation of the war potential. It was the maintenance of a marked delimitation line in the conditions of a mountainous region, non-interference with the life mode of the neighbours, mutual exchange of vital products including the terms of the exploitation of winter pastures in the steppe as the epicentre of the habitation of the nomads. 